\title{
Current Challenges and Prospects of Indonesian Non-Timber Forest Products (NTFPs): A Review
}

\author{
Gunawan Pasaribu ${ }^{1, *}$, Ina Winarni ${ }^{1}$, Raden Esa Pangersa Gusti ${ }^{1}$, Rizki Maharani ${ }^{2, *}$, Andrian Fernandes ${ }^{2}$, \\ Alfonsus Hasudungan Harianja ${ }^{3}{ }^{(D}$, Grace Serepina Saragih ${ }^{3}$, Maman Turjaman ${ }^{4}$, \\ Agustinus Panusunan Tampubolon ${ }^{4}$, Harlinda Kuspradini ${ }^{5}$, Ganis Lukmandaru ${ }^{6}$, \\ Gerson Ndawa Njurumana ${ }^{7}$, , Agus Sukito ${ }^{8}$, Aswandi Aswandi ${ }^{9}$ and Cut Rizlani Kholibrina 9
}

Citation: Pasaribu, G.; Winarni, I.; Gusti, R.E.P.; Maharani, R.; Fernandes, A.; Harianja, A.H.; Saragih, G.S.; Turjaman, M.; Tampubolon, A.P.; Kuspradini, H.; et al. Current Challenges and Prospects of Indonesian Non-Timber Forest Products (NTFPs): A Review. Forests 2021, 12, 1743. https:// doi.org/10.3390/f12121743

Academic Editor: Apostolos P. Kyriazopoulos

Received: 4 October 2021

Accepted: 4 December 2021

Published: 10 December 2021

Publisher's Note: MDPI stays neutral with regard to jurisdictional claims in published maps and institutional affiliations.

Copyright: (c) 2021 by the authors Licensee MDPI, Basel, Switzerland. This article is an open access article distributed under the terms and conditions of the Creative Commons Attribution (CC BY) license (https:/ / creativecommons.org/licenses/by/ $4.0 /)$.
1 Forest Products Research and Development Center, Bogor 16119, Indonesia; inawinarni@yahoo.com (I.W.); resapangersag@gmail.com (R.E.P.G.)

2 Dipterocarp Ecosystem Research and Development Centre, Sempaja Selatan, Samarinda 75119, Indonesia; af.andrian.fernandes@gmail.com

3 Center for Standardization of Environmental Quality Instruments, Jalan Raya Puspiptek Serpong, Tangerang Selatan 15314, Indonesia; alfonsus@menlhk.go.id (A.H.H.); graceserepina@gmail.com (G.S.S.)

4 Forest Research and Development Center, Bogor 16119, Indonesia; turjaman@gmail.com (M.T.); agustampu10@gmail.com (A.P.T.)

5 Faculty of Forestry, Mulawarman University, Gunung Kelua, Samarinda 75119, Indonesia; hkuspradini@fahutan.unmul.ac.id

6 Department of Forest Products Technology, Faculty of Forestry, Universitas Gadjah Mada, Bulaksumur, Yogyakarta 55281, Indonesia; glukmandaru@ugm.ac.id

7 Environment and Forestry Research and Development Institute of Kupang, Airnona, Kota Raja, Kupang 85115, Indonesia; njurumana@gmail.com

8 Research and Development Institute of Non-Timber Forest Product Technology, Lombok Barat 83371, Indonesia; sukitokun@gmail.com

9 Research and Development Institute of Forest Fiber Technology, Bangkinang Riau 28463, Indonesia; andiasw@yahoo.com (A.A.); rizlanicut@gmail.com (C.R.K.)

* Correspondence: gun_pa1000@yahoo.com (G.P.); rizma_annisa@yahoo.com (R.M.)

Abstract: Non-Timber Forest Products (NTFPs) management can lead to various benefits for community livelihood and forest sustainability. However, such management has not been carried out optimally and sustainably in Indonesia, due to various limiting factors including ineffective policies, undeveloped cultivation technologies, and inadequate innovation in processing technologies. Further, the diversity of NTFPs species requires that policy-makers determine the priority species to be developed. Agarwood (Aquilaria spp. and Gyrinops spp.), benzoin (Styrax spp.), sandalwood (Santalum album L.), and cajuput (Melaleuca cajuputi Powell) are aromatic NTFPs species in Indonesia that forest-dwellers have utilized across generations. This paper reviews the current governance, cultivation systems, processing and valuation, and benefits and uses of these species. We also highlights the future challenges and prospects of these NTFPs species, which are expected to be useful in designing NTFPs governance, in order to maximize the associated benefits for the farmers and all related stakeholders.

Keywords: agarwood; benzoin; cajuput; cultivation; governance; NTFPs; processing technology; sandalwood

\section{Introduction}

The export value of Indonesia's timber forest products reached USD 11.6 billion in 2019. Meanwhile, the export value of non-timber forest products (NTFPs) was not reported [1], although some of the 150 globally traded NTFPs commodities [2] potentially originated from Indonesia. This condition is not in line with the area of Indonesia's forests and the variety of NTFPs. There are 496 plant species listed as NTFPs resources utilized in Indonesia [3], but only a few contribute to the country's foreign exchange. The primary 
NTFPs export commodities are rattan and turpentine, even though many other potential NTFPs have good potential to be developed [4].

The roles of NTFPs to provide income for indigenous people or populations around forests as well as for conservation have been investigated by scholars. Farmers allocate their cash income from NTFPs to obtaining farming inputs, purchasing food or basic needs, savings, and to finance health costs [5-7]. In many countries, income gained from NTFPs is used by rural communities as additional capital, supporting their financial security in difficult times [8-11]. The extraction of NTFPs, in general, is considered to minimize threats to forest sustainability, despite the fact that some practices, such as the premature harvesting of flowers or fruit, might affect the natural regeneration process [12-14]. In contrast to timber extraction, the utilization of plant parts, such as sap, resin, leaves, fruits, or other tree parts, with proper techniques minimalizes the risks to the trees.

Nevertheless, there are various problems involved with the management of NTFPs, including technical and policy-related issues. Although the extraction of NTFPs has been conducted across generations, involving approximately $80 \%$ of the population of developing countries, and some products have been exported from Asia to Europe historically [15], the prospect of their international exchange is still not as attractive as that for timber [2]. Due to the minimum innovation and technology in the post-harvesting process, the NTFPs have the least added value of all forest products $[16,17]$. Plant productivity is also dependent on their nature, as the cultivation innovation and technology remain relatively are undeveloped. Some NTFPs are only available in certain seasons, according to the natural production period $[8,18,19]$; therefore, it becomes a challenge to meet the demand when it is not the harvest season of certain NTFPs. Biotechnology to modify the production or processes for specific NTFPs is important.

Regarding the development of NTFP's, previous studies identified challenges for NTFPs governance, including policy interventions $[10,20,21]$, access rights $[22,23]$ to the tree or land tenure $[6,24,25]$, market information $[16,26]$, market prices $[11,27,28]$, and institutional regulation [22,29]. Contrary to the developing forest governance in timber products, the challenges of NTFPs governance are still a huge problem in Indonesia. This paper elaborates on the state of development of four popular NTFPs in Indonesia: agarwood, sandalwood, benzoin, and cajuput. All commodities can be established as the forest dwellers have inherited their cultivation and processing techniques, and the products all have prospective economic value.

Agarwood, benzoin, sandalwood, and cajuput oil are essential oils, which are classified as secondary metabolite groups. Secondary metabolites play a role in the defense system of plants. Plant secondary metabolites can be divided into three main groups: terpenes, phenolics, and nitrogen and sulfuric compounds [30,31]. Essential oils from aromatic plants have been extensively used as natural organic mixtures and remedies in almost every field. As such, their market is rapidly growing [32]. Essential oils have been effectively applied as a medicinal treatments for various diseases, including infectious diseases, depression, anxiety, and pain relievers, due to their activity as anti-fungal, antimicrobial, anti-cancer, and wound-healing activities. Furthermore, they have also been used to manufacture cosmetics and fragrances [32,33].

Agarwood is an aromatic product which is in great demand overseas. This fragrant wood is a resinous part of the tropical tree of the Aquilaria and Gyrinops species, and is a highly economical product for incense, medicine, the perfume industry, and aromatic food ingredients [33]. The national agarwood production in 2019 only reached 76.05 tons [1]. This production value is relatively low, compared to the area of an agarwood plantations, which is quite massive from the western to the eastern part of Indonesia [34]. Indonesia is far behind other ASEAN (Association of Southeast Asian Nations) countries for agarwood cultivation. Planting activities of agarwood-producing trees in Indonesia are carried out by small-scale forest communities ranging from 10-5000 trees per farmer, while Malaysia, Thailand, Vietnam, and Cambodia plant large-scale plantings of up to more than 
1000 hectares, carried out on a large scale by large companies and in collaboration with foreign investors [35]. In contrast, Indonesia is still dependent on natural agarwood.

The benzoin (Styrax spp.) is a commodity in Indonesia which is very slow in development. Although the area and the production of benzoin plantations/forests in North Sumatra Province of Indonesia tended to increase slightly from 2017 to 2019 [36], previous research has pointed out some problems related to its cultivation, harvesting, and marketing $[28,37,38]$. Land conversion to industrial forest plantations and seasonal agriculture also threatens these resin-producing tree stands. Benzoin trees grow ideally in association with other trees, such as pine (Pinus sp.), andaliman (Zanthoxylum acanthopodioum DC.), and antarasa (Litsea cubeba (Lour.) Pers.), such that maintaining the forest, according to its density level can increase the productivity of biomass and resin from benzoin.

Meanwhile, sandalwood (Santalum album L.) is a commodity which is experiencing production degradation, in both the natural and plantation contexts. The sandalwood distribution in Indonesia, found in Java, Sumba, and Timor, has been degraded genetically and/or reproductively due to anthropogenic and natural disruptions [39]. Even though sandalwood is one of the leading commodities contributing to the local economy of some districts in the eastern part of Indonesia, the government's policy has not supported the development of this species [40]. These governmental policies rule out the local people's right to the economic share of the sandalwood harvest, and has prevented them from taking part in sandalwood regeneration projects in the past [40]. However, cultivation techniques have been designed by an Indonesian researcher, in order to sustain the preservation of these plants [41].

Cajuput oil is produced through the distillation of cajuput (Melaleuca cajuputi Powell) leaves. The national cajuput oil production has not been able to meet domestic needs [42] Thus, cajuput oil is generally imported to meet the demand. The cajuput enterprise has long been developing in Indonesia, but has not met the high demand. Cajuput oil became a potential therapy to relieve symptoms associated with coronavirus desease. Based on a study in Vietnam, cineole-the active compound of cajuput-shows potential as an antiviral agent [43], besides its anti-inflammatory and immunomodulatory activites [30].

NTFPs harvested from natural and cultivated forests differ in several aspects, including the location and mode of harvesting, yield availability, product quality, and potential regeneration. The yield of natural NTFPs harvested from the forest is unpredictable as it depends on natural production $[44,45]$. On the contrary, the production of NTFPs cultivated in plantation areas can be projected $[46,47]$. As an example, agarwood products can be targeted to a definite yield range after inoculation. As natural NTFPs' production depends on the natural condition of the site, the quality of the products fluctuates and is uncontrollable [48], different from the quality of planted NTFPs. Proper silviculture technology may increase the NTFPs' yields; for example, the cineole quality of cajuput produced by breeding is higher than that of natural cajuput. The potential regeneration of natural NTFPs is uncertain, due to the absence of successive plants maintenance, while cultivated plants feature a higher regeneration or succession rate, making their use manageable $[49,50]$.

This study aims to describe the current state of the four abovementioned NTFPs in Indonesia, including the governance, cultivation system, harvesting and processing, benefit and utilization, value chain, and product diversification, through the use of semi-systematic review. We also highlights the challenges and prospects of the NTFPs in the future, which is expected to be useful for designing NTFPs governance, specifically in Indonesia, in order to maximize the benefits for the farmers and all related stakeholders.

\section{Methods}

For this paper, we conducted a semi-systematic or narrative review [51]. The literature was searched using the Google Scholar, Scopus, science direct, and ResearchGate portals. Some terms (in Bahasa Indonesia-denoted in italics- and English) were combined during the literature search, including: agarwood, benzoin, cajuput, cendana, economy, gaharu, hasil hutan bukan kayu, HHBK, kayu putih, kemenyan, livelihood, medicinal plant, non-timber 
forest product, NTFP, pemasaran, plantation, sandalwood, and styrax. The articles included were written in Indonesian (Bahasa Indonesia) and English. The publication years was restricted from 1996 to 2020. Both published and unpublished articles, such as regulations, peer-reviewed journal articles, books, proceedings, reports, theses, and online articles, were grouped (see Table 1), and then analyzed.

Table 1. Reviewed publications.

\begin{tabular}{|c|c|c|}
\hline Theme & Number of Literature & References \\
\hline Governance & 29 & {$[1,3,12,14,16,20,25,29,52-72]$} \\
\hline $\begin{array}{l}\text { Marketing, trading, } \\
\text { production, and } \\
\text { cultivation }\end{array}$ & 51 & {$[4,28,36,38,41,42,73-117]$} \\
\hline $\begin{array}{l}\text { Phytochemistry, genetic, } \\
\text { ethnobotany, and } \\
\text { biological activity }\end{array}$ & 69 & {$[30-33,118-182]$} \\
\hline $\begin{array}{l}\text { Sustainability and } \\
\text { conservation }\end{array}$ & 19 & {$[2,11,19,37,39,183-196]$} \\
\hline Socio-economy & 17 & {$[5-10,13,15,17,18,21-24,27,50,197]$} \\
\hline
\end{tabular}

\section{Results and Discussion}

\subsection{Governance}

The governance of NTFPs is often considered to be embedded in forestry governance in general. In contrast, the management of NTFPs has some different characteristics, associated with the number of parties or the human resources involved; the uncertainty of land or trees rights; traditional cultivation, harvesting and processing technologies; the short storage time of the products; and limited market access. Governance creates mutual interactions among parties in applying governance institutions and arrangements to result in better value chains [114,194]. Beyond timber benefits, NTFPs provide ecological, social, and economic dimensions. Therefore, the integration of NTFPs utilization in forest management should support community livelihood, conservation, and socio-cultural means [14].

Forest governance can be defined as the act of implementing the forest policy [71], as a part of social science [66]. Forest governance is an attempt to regulate the use, access, management, and conservation of forest resources by using a social approach, considering social, economic, and governmental interests [66]. Forest governance encompasses agreements to achieve the accepted goals among stakeholders, based on rules and norms, the rights and obligations of the owners, how to participate in the decision-making process, the shape of the distribution of benefits, the responsibility of labor, and the position of the roles, work, and accountability [66]. Consequently, all stakeholders must be responsible and respectful to the agreement, whether written or verbal $[66,70]$.

Good forestry governance is formulated as institutional mechanisms in the management of forest resources according to applicable law, accountability, transparency, democracy, fairness, decency, efficiency, equity, sustainability, and the participation of stakeholders [52,71,72]. In practice, forest governance is associated with the government, authority, and territoriality. The concept of territorial boundaries includes the actual technical and administrative processes, which includes the forest resources [69]. Conceptually, governance is determined with respect to the actor's roles, authority, and resources; rules or regulations; and discourse related to the management system [67].

Forest governance at the global level is likely to be too technical and bureaucratic, and is still significantly lacking in the inclusion of social-ecological perspectives [68]. Likewise, forest governance in Indonesia has been characterized by legal uncertainty on access to resources and land ownership [69] in the past. A centralized system characterized forest management in Indonesia in the colonial period, with a main focus on timber extraction, which was continued in the New Order through the Mining Law 1967 and Forestry Law 
1967 [53]. Forest management was very commercial, and the government generally granted forest concession rights to companies. After the reformation in 1998, the government has paid more attention to community rights, granted new access rights, and has followed land reform policy over the past ten years $[67,69]$.

NTFPs governance requires a thorough understanding of the complexity of the NTFPs development problem [115]. Due to the complexity of the problem, the community and the government are not the only actors in NTFPs governance, although presence of a stable government can allow the NTFPs to not stay trapped in the gray economic status. Environmental and natural resources management requires the involvement of various stakeholders at different levels. It also requires an inter-village and outside village network, which is dynamic and involves different types of diverse actors with varying interests [54]. Previous research $[16,55]$ have stated that governance challenges are more specific, requiring regional and inter-regional collaboration and involving private sectors that usually provide more innovation and entrepreneurship. The management of NTFPs in Indonesia is necessary due to their strategic social, economic, and ecological roles. The national policy is set through the Ministry of Forestry Regulation No. P.35/2007 concerning NTFPs, which states that there are 558 NTFPs commodities in Indonesia. This was followed by the Ministry of Forestry Decree No P.19/2009 on the development strategy of NTFPs and P21/2009 on the criteria and indicators of NTFPs priorities.

In order to promote the contribution of NTFPs to economic development, the Government of Indonesia started to reorganize the management of NTFPs in 2007. However, before that, Indonesia had already ratified the Convention on Biological Diversity (CBD) in 1994 and the Convention on International Trade of Endangered Species of Flora and Fauna (CITES) in 1978, in order to regulate the international trade of NTFPs derived from plants that are classified as endangered species, including agarwood. Likewise, with sandalwood, the East Nusa Tenggara Provincial Government has regulated sandalwood exports since 1966, and the central government has regulated the trade of cajuput oil on Buru Island, Maluku, since 1956. The regulations issued since 2007 are more focused on defining NTFPs as a non-timber biological resource produced from both natural and cultivated forests, criteria for determining the priority of NTFPs development, NTFP development strategies, and permits, and quotas for the use of several NTFP commodities, such as rattan and agarwood.

These regulations have not yet established good NTFPs governance. The balance between utilization and conservation [198] has not been considered in the ultimate requirements of NTFPs sustainability. The regulations have not sufficiently strengthened the value chain of NTFPs to the farmers as producers [199], implemented adaptive management, strengthened the farmer economic institutions, enhanced trade and market information, set floor prices, provided incentives, and improved cross-sectoral coordination [195], as has been successfully conducted in rattan management. Such improvement to the NTFP regulations began in 2020, with the issuance of the Omnibus Law, and followed in 2021 with the issue of Governmental and Ministry of Environment and Forestry regulations which deregulated licensing (i.e., there is only one permit for both forest management and NTFP). The landscape-based multiple-use forest management is expected to promote the sustainability of NTFPs [200].

The policies and management strategies for agarwood, benzoin, sandalwood, and cajuput are based on central government regulations issued since 2007. However, considering that the four NTFP commodities have high economic values and involve many parties in their management and marketing, the regulations were preferably detailed at the Director-General and Local Government levels. Agarwood cultivation in Indonesia and benzoin in North Tapanuli, North Sumatra, were regulated by the relevant DirectorGeneral, while local governments issued utilization permits and quotas in the regions where these resources are being developed. The current condition indicates that cultivated agarwood resin has not yet been found in the export market, and wholesalers still rely on natural agarwood $[73,192,201]$. The price of benzoin resin also fluctuates sharply. The 
uncertainty of product grade is caused by farmers not being enthusiastic about growing benzoin plants and tapping their resin, especially younger benzoin farmers [65]. Regulations for the two NTFP commodities that led to improved management and development of NTFP plantations were ineffective, and wholesalers dominated the utilization of NTFPs, as they are the stakeholders that have access to international market information [28,202].

A similar circumstance has occurred for sandalwood where the East Nusa Tenggara Provincial Government Regulation in 1966 only provided 1\%-10\% benefits for farmers from the existing value chain [53], resulting in rising conflict and sandalwood overexploitation [183], which eventually led to the International Union for Conservation of Natural Resources (IUCN) categorizing sandalwood as vulnerable in Appendix II CITES [196]. Regulations that did not favor community strengthening led to the over-exploitation of sandalwood which had begun before the Portuguese and the VOC colonization, and which continued until the end of the New Order Era in 1999 [56]. On one hand, the local government did not recognize that the community's land was overgrown with sandalwood. On the other hand, sandalwood management was utilized as a state control to society [57]. The situation has led to prolonged conflicts, and the farmers no longer value sandalwood, culminating in collective action to fight through the extermination of natural sandalwood regeneration on their private land $[58,183,196]$. In the end, the Government realized this mistake and issued a Provincial Regulation in 2012, which aimed to build trust and heal traumatized farmers to realize sustainable sandalwood management.

The regulation of cajuput has been carried out since 1956 as the Applicability Statement of the "Ordonnantie Aetherische Olien" Regulation for cajuput oil [203]. This regulation aimed to stop monopolization and price manipulation of cajuput essential oil, which was detrimental to the community by traders on Buru Island [74]. To date, the cajuput oil trading system has not supported an efficient cajuput industry. Six parties are involved in this system, namely: (1) cajuput leaf producers (plantation forest manager), (2) cajuput refiners, (3) cajuput traders, (4) processing and packaging factories, (5) cajuput oil distributors, and (6) cajuput oil retailers (or pharmacies) [116]. The Minister of Industry issued a Road Map for the Essential Oil Industry Cluster Development in 2009, in order to strengthen the economic contribution of cajuput. Through this policy, Indonesia is projected to become one of the five leading producers of cajuput essential oil globally, and each province in Indonesia should develop at least one essential cajuput oil production center.

Agarwood is traded in sapwood or essential oil form, which is produced by the agarwood distillation process. The quality of agarwood highly depends on the resin matter and the agarwood sapwood dye [75]. Harvesting natural agarwood trees in the forest without sufficient replacement threatens the presence of natural agarwood. In addition, agarwood can also be obtained through the extraction of agarwood buried due to natural processes (i.e., decaying logs), which is mostly carried out in the Papua region [117].

Natural agarwood production has continued to decline since 2010, due to overharvesting and forest conversion to other uses [73]. At present, many groups of farmers are interested in agarwood cultivation to increase production through inoculation techniques. However, the production of cultivated agarwood is still hampered by the regulation on the export quota of agarwood, which is similar to that of natural agarwood. Agarwood is listed in the Conservation on International Trade in Endangered Species (CITES) of Wild Fauna and Flora, setting the associated exchange quotas. The government and farmers need to build cooperation to respond to these challenges. The formation of the ASGARIN (Indonesian agarwood exported association) may bridge the interests of those stakeholders, in order to set up better agarwood governance.

Indonesia's agarwood export markets include Middle Eastern countries and China. Agarwood is usually exported in the form of sapwood, which is used for its aroma. A report from the Ministry of Environment and Forestry in 2019 stated that Indonesia's agarwood production only reached 76.05 tonnes [1]. Thus, efforts are needed to increase national agarwood production through the reformation of regulations and policies. 
Benzoin resin demand originates from domestic and international markets, resulting in high economic value and contributing significantly to the household economy of the farmers. The marketing chain involves traders at the village, sub-district, regency, and exporter levels $[38,65,77]$. Related to the marketing system, the farmers lack price information and price distortions are relatively high in the middle-man marketing chain at the village, sub-district, and exporter levels [38]. Farmers do not have a strong bargaining position against the selling price in all marketing chains. Farmers, therefore, are price-takers and do not have direct access to the exporter, which is generally located in the capital of North Sumatra Province $[65,77]$. The local government has not yet supported styrax development, either in regulation or market intervention.

The quality of cajuput oil traded in Indonesia must comply with Indonesian National Standards (SNI) 3954:2014 for Cajuput Oil. Indonesia imported 2000 tonnes of cajuput oil in 2019 to fulfill the 4500-tonnes cajuput oil demand. Domestic production has not met the demand for cajuput oil, so eucalyptus oil was also imported as a complement [79]. Cajuput oil has been widely used to relieve breathing and reduce inflammation. The results of a study stated that chemical compounds present in cajuput, such as cineole, terpineol, guaiol, inalool, $\beta$-Selinenol, $\alpha$-Eudesmol, and $\gamma$-Eudesmol, have potential for anticoronavirus activities [43].

The Central Bureau of Statistics of Indonesia has reported fluctuations in cajuput leaves production. The lowest production in the 2011-2021 period was in 2012, which was $17,309,982 \mathrm{~kg}$. In contrast, the highest production was in 2019, which was 40,514,739 kg [80]. The supply of cajuput oil in Indonesia comes from two business scales categories; namely small- and large-scale industries or cajuput oil factories. Perhutani (the Indonesian state forestry company) and KPH (Forest Management Unity) Yogyakarta are the largest producers of cajuput oil in Indonesia. Perhutani processed 41,649 tonnes of cajuput leaves and sold 322 tonnes of cajuput oil, worth IDR 85 billion in 2019 [81]. Perhutani has eight cajuput oil factories located in Banten, Central Java, East Java, and West Java. KPH Yogyakarta has two cajuput oil factories, Sendang Mole and Jadian, and produced 34,725 L of cajuput oil in 2017 [82]. Maluku province was once a large producer of cajuput oil. In 2017, the province produced 105,130 L of cajuput oil, which increased to 161,870 L in 2018 [112,113]. In Maluku province, there are more than 100 refinery units spread over four districts [204].

The problem with small-scale cajuput oil agroindustry is that the farmers tend to be price-takers, and the price they receive is much lower than the price at the retailer level [84]. Moreover, essential oil products from Indonesia lack uniqueness [61]. Increasing economic value for cajuput oil-producing areas can be achieved through legal protection, using a Geographical Indication scheme [62,205].

\subsection{Cultivation System}

Indonesia has a high diversity of agarwood-producing trees species. The major cultivated agarwood species are Aquilaria malaccensis Lam., A. microcarpa, and Gyrinops versteegii. The population of agarwood in Indonesia has reached 3.4 million trees. The highest population is located in Central Kalimantan (24.7\%), followed by North Sumatra $(17.9 \%)$ [34]. The success of agarwood cultivation is determined by proper inoculation methods. Inoculation methods can divided into two groups: physical wounding methods (e.g., by drilling, nailing, or pruning) and biological methods (e.g., by introducing a microbial culture into the tree). Biological methods are more productive than the physical wounding methods $[85,94]$. However, this technology is not yet widely implemented. Until now, agarwood cultivation has been carried out by the community without significant support from the government.

Different from agarwood, sandalwood has been designated as s strategic NTFPs species, and has received sufficient support from the local government of the Nusa Tenggara Timur (NTT) Province, a province in the eastern part of Indonesia. Although sandalwood has been exported since 1436 from NTT [59], sandalwood production from Indonesia is relatively small, especially in terms of the market share in the international market. 
From 1910-1916, sandalwood production from NTT reached 917,125 Kg [59], for a total production of 2,458,594 Kg in that period [206]. The share of sandalwood in the economy of NTT was $38.26 \%$ on average during 1989/1990-1993/1994 and $12.17 \%$ during 1995/1996-1999/2000 [76]. At present, the contribution of sandalwood is smaller, due to the scarcity of natural sandalwood populations. Various replanting efforts have not shown results, due to difficulty of the associated propagation techniques, such that the development of new populations is limited. Furthermore, policy transformation in sandalwood management through various replanting programs has not produced significant results, due to the long production cycle of sandalwood.

A better scheme has been applied for Styrax cultivation management. As an endemic species in the Tapanuli highlands of North Sumatra Province [37,65,121], the plantation area in North Tapanuli Regency covers $22.670 \mathrm{Ha}$ and produces $321.3 \mathrm{~kg} / \mathrm{ha} / \mathrm{yr}$ resin on average (or 4.247 tonnes/yr [121]. The influence of local customs and culture also supports the sustainability of this NTFPs species. Stand and land management are similar to other land-use systems in traditional Batak customary rights. Benzoin forest is acquired and then inherited, based on Batak customary law occupying a patrilineal system [38]. The current tenurial status of styrax forest is private, clan, customary, or leased $[37,65]$. There is no unique management setting for privately owned or leased styrax forest.

An explicit arrangement is applied to the customary styrax forest. This forest has been cultivated for more than 3-4 generations [65]. Some studies have stated that the cultivation has been carried out for more than 13 generations [37,60], and it still exists to this day. The farmers cultivate styrax in groups. The membership of the group can only be inherited by the oldest son of each family. If the first son dies or does not live in the village, the membership is passed down to the second son, and so on. Harvesting of styrax resin is decided through a meeting of the members. The original members of the group can utilize customary land that is currently fallow. The land that the individuals manage can be owned privately, as long as they can manage it by themselves without the help of other members and do not use machine tools. If the land is sold, the person is prohibited from opening up a new area in that customary land. Challenges related to the land tenure system of styrax forests include conflict with the forest plantation industry that operates in some of the styrax forests in North Sumatra [37].

Farmers have also adopted local wisdom to support sustainability. Some sustainable cultivation techniques include limiting the harvesting period and the number of bark wounds. Resin harvesting is carried out periodically-only twice a year-with the number of tapping points adjusted to the size of the tree. For small to medium-sized trees, tapping points are only carried out on one pollang (about $1.5 \mathrm{~m}$ ) with four tapping holes; while, for large trees, the tapping points are carried out on two pollang with eight scattered tapping points. Moreover, local farmers also only take care of the best young trees that grow around trees with high productivity as a long-term investment.

Cajuput (Melaleuca cajuputi subsp cajuputi) initially grew in Ambon, Buru, Seram, and Timor Island [78]. Formerly, this plant was known as Melaleuca leucadendron (L.) L., and its oil is often equated with eucalyptus oil. Oil concentration and 1.8-cineole are the crucial determinants of the economic value of cajuput oil [122]. In contrast to other types, eucalyptus cultivation has been carried out on large-scale plantations for the production of essential oils.

In general, the silviculture system of NTFPs species in Indonesia is still underdeveloped. Agarwood, benzoin, and sandalwood cultivation follow a traditional silvicultural system with minimal applications of technology, while a relatively advanced silvicultural system has been applied to cajuput commodities. The supporting factor is that the cajuput commodity has been managed on a company scale and involves the cooperation of local governments and the private sector. In summary, innovation in cultivation technology is urgent for all NTFP species, in order to increase their productivity and sustainability. 


\subsection{Processing and Valuation}

\subsubsection{Harvesting}

Agarwood-producing trees can be harvested after one year of inoculation, although waiting three-year harvest produces the best quality. Harvesting is done by manually, cutting down every 2-3 $\mathrm{m}$ of the stems using a machete or axe. The use of mechanical appliances degrades the yield quality. All items are transported to the scraping site, as the processing stage is not carried out in the forest or garden. According to the government regulations complying with CITES, official papers must accompany the transportation of agarwood stems, in order to avoid illegal vindication. The scraping should be done by skilled persons, in order to obtain a high quality product without white wood residue. The proper scraping process using standardized tools will increase the price of agarwood up to $100 \%$ of the highest-grade value as a pre-requisite by industrial means [86].

Unlike the process of agarwood inoculation, benzoin is produced by the styrax plants themselves inside the epithelial tissue of their wounded bark [87]. Therefore, bark wounding is the pre-eminent method for the plants to produce the resin. Traditionally, the harvesting process is done using manual gears, including a guris for cleaning the bark, a tuhil for tapping, a peeler-scraper, climbing ropes, baskets, and drying mats [88]. The tapping process is started by scrubbing the bark and trunk surface. Then, eight to twelve tapping holes on each tree are created by penetrating the bark surface, resulting in a space between the bark and cambium. The wound size is five to ten $\mathrm{cm}$ in width. Then, the bark is re-sealed by hitting the bark surface gently. The gaps created in the inner bark will be full of liquid resin, which hardens in three to four months. The farmers then collect all of the resins, mixed with the bark pieces [88]. The average resin productivity is $1.291 \mathrm{~kg} /$ tree.

The conventional method to produce resin yields approximately $1.526 \mathrm{~kg} /$ tree $[88,89]$. A modified conventional method, by creating a larger wound to accommodate resin, can result in higher yields, up to $1.728 \mathrm{~kg} /$ tree $(13.2 \%)$. Considering that farmers can harvest around ten trees per day, there is a significant increase in production, accounting for $1.92 \mathrm{~kg}$ of raw resin daily. Therefore, this alternative method is more practical and feasible to be applied in benzoin harvesting on a widespread scale.

The parts of the sandalwood tree that are utilized are the trunk and roots [123]. Harvesting sandalwood begins with extracting the roots, clearing branches and twigs, bucking the trunk, and transporting logs. This harvesting technique is similar to that performed by the local community in the NTT Province [184]. The technique of harvesting sandalwood trees is done manually, which is different from other commercial tree-harvesting mechanical techniques such as that used for harvesting trees of the Dipterocarpaceae family [185]. The sandalwood-collecting technique conducted by the Mukim community is similar to the tree-length logging method in natural forest harvesting [90]. It has a limiting factor; namely, the minimum diameter and the process of removing tree roots. The main part producing the fragrant santalol compound is the heartwood. On the other hand, root extraction in sandalwood harvesting reduces tree regeneration potential, whereas seed regeneration results in low growth potential [63]. The efficiency of sandalwood harvesting is only $66.46 \%$, lower than the efficiency of harvesting trees in natural forests, which can reach $74 \%-75 \%$ [185]. Sandalwood tree harvesting refers to the diameter and ratio of the wood core. The sandalwood traded should have a minimum diameter of $2.5 \mathrm{~cm}$, length of $100 \mathrm{~cm}$, proportional heartwood, and no cracked or rotten parts of the wood [64].

Cajuput leaves will be ready for harvest at the age of 3 years, when the oil content is maximum. Pruning cajuput leaves should be done at the age of 9-12 months, in order to increase the yield. To facilitate the harvesting of leaves, cajuput trees are cut at $1.5 \mathrm{~m}$ height. Cajuput leaf harvesting is carried out periodically, every 9-12 months. The best time for harvesting is in the dry season [78], and harvesting is generally stopped during the rainy season, due to the high water content in leaves.

In general, the processing of raw materials depends on the end-product to be obtained and the characteristics of the original material. Considering that the four NTFPs are aromatic products, two extraction methods are generally applied: (a) extraction with 
solvents and (b) steam distillation $[88,124]$. Simple processing, including sorting or cleaning the woody part of the resin, can be applied-especially to produce higher quality agarwood incense. The production of fragrant oils of agarwood, sandalwood and cajuput typically uses steam distillation $[91,92]$. This technique has also been applied in a limited manner to produce essential oils from benzoin resins [88].

\subsubsection{Benefit and Uses}

Historically, traditional rituals-especially those related to the world of spirits-use agarwood [95], sandalwood [186], and benzoin [96] through various methods such as burning, powdering, or in the form of incense. Cajuput is used for aromatherapy [140]. Agarwood is used as a qi-regulating drug and carminative medicine to lessen gastric problems, rheumatism, asthma, coughs, and high fever in traditional Chinese medicine [141]. Arabian medicine also uses essential agarwood oil for aromatherapy. In other countries, including Indonesia, agarwood has also been widely used as an incense in religious rituals for centuries [142].

The quality of agarwood, based on the resin content, strongly influences the selling price of natural agarwood which can be divided into agarwood sapwood, agarwood pomegranate, and agarwood ash. The latter is also historically cheaper, as it has the lowest resin content. The agarwood quality has been determined in the Indonesian Standard SNI Gaharu 01-5009.1-1999, and been revised in SNI 7631: 2011 [125]. Aquilaria malaccensis Lamk. (A. malacensis) and Gyrinops versteegii (Gilg) Domke (G. versteegii) are the most commonly used species, which can still be found in Indonesian forests. Agarwood oils from $A$. malaccensis contained several sesquiterpenes, such as sesquiterpenes alcohols, oxygenated compounds, hydrocarbons, and acids. Six out of forty-three compounds detected in agarwood essential oil are considered as remarkable compounds: 4-phenyl-2-butanone, valencene, curcumene, $\beta$-dihydroagarofuran, 10-epi- $\gamma$-eudesmol and $\alpha$-guaiene. The rest of the compounds included $\alpha$-gurjunene, $\beta$-copeane, $\gamma$-elemene, aromadendrene, valencene, $\gamma$-gurjunene, elemol, and $\beta$-vetivenene, among other compounds. Aromadendrene, $\beta$-agarofuran, 10-epi- $\gamma$-eudesmol, and $\gamma$-eudesmol have also been reported as significant compounds in A. malaccensis agarwood oil [126].

Aromadendrene compounds can act as an effective chemical determinants for agarwood. These chemical compounds characterize agarwood: the higher the aromadendrene content, the better the quality of agarwood oil [125]. In its various forms, such as oil, wood, powder, and plant (Figure 1), agarwood has been used to improve health and treat various illnesses, including for the treatment of mothers after giving birth and diseases of the female genital organs. It is also applied to alleviate spasms in the gastrointestinal and respiratory systems. In addition, it has been applied to cure asthma, abdominal pain, chest congestion, diarrhea, hiccups, nausea, nerves, colic, mental disorder, and cancer, and for the treatment of regurgitation and malnutrition [97-100,143,146].

Malaysians, Indians, and Chinese use agarwood oil mixed with coconut oil as a lotion for treating various skin diseases. Furthermore, agarwood oil can be used in a decoction to cure rheumatism, lung disease, stomach tumors, carminative diuretic, and other body pain $[99,100]$. Traditional Chinese and Japanese medicine utilizes high-grade agarwood as a sedative, analgesic, and digestive agent $[101,148]$. It is also applied in pharmaceutical tincture production $[102,103]$. The properties of agarwood have been utilized for antiasthmatic, tonic, stimulant, aphrodisiac, carminative, and astringent purposes in India, Bangladesh, and Egypt [143].

Sandalwood is a hemiparasitic root tree. Its wood is highly aromatic, and it is the secondmost expensive wood after African Blackwood (Dalbergia melanoxylon Guill. \& Perr.) [127]. The aromatic oil of sandalwood accumulates in the tree's heartwood and roots for 15-20 years. The main compounds of the oil are (Z)- $\alpha$-santalol (25.34\%), (Z)-nuciferol (18.34\%), (E)- $\beta$ santalol (10.97\%), and (E)-nuciferol (10.46\%) [128]. However, sandalwood oil quality is characterized by santalol content. The santalol content is quantified using gas chromatography (GC), with a proposed range of $\geq 43 \%$ for Z- $\alpha$-santalol and $\geq 18 \%$ for Z- $\beta$-santalol [118]. 
Sandalwood oil is employed largely as an astringent, sedative, coolant, and disinfectant in the bronchial and genitourinary tracts, as well as an expectorant, stimulant, and diuretic [147].

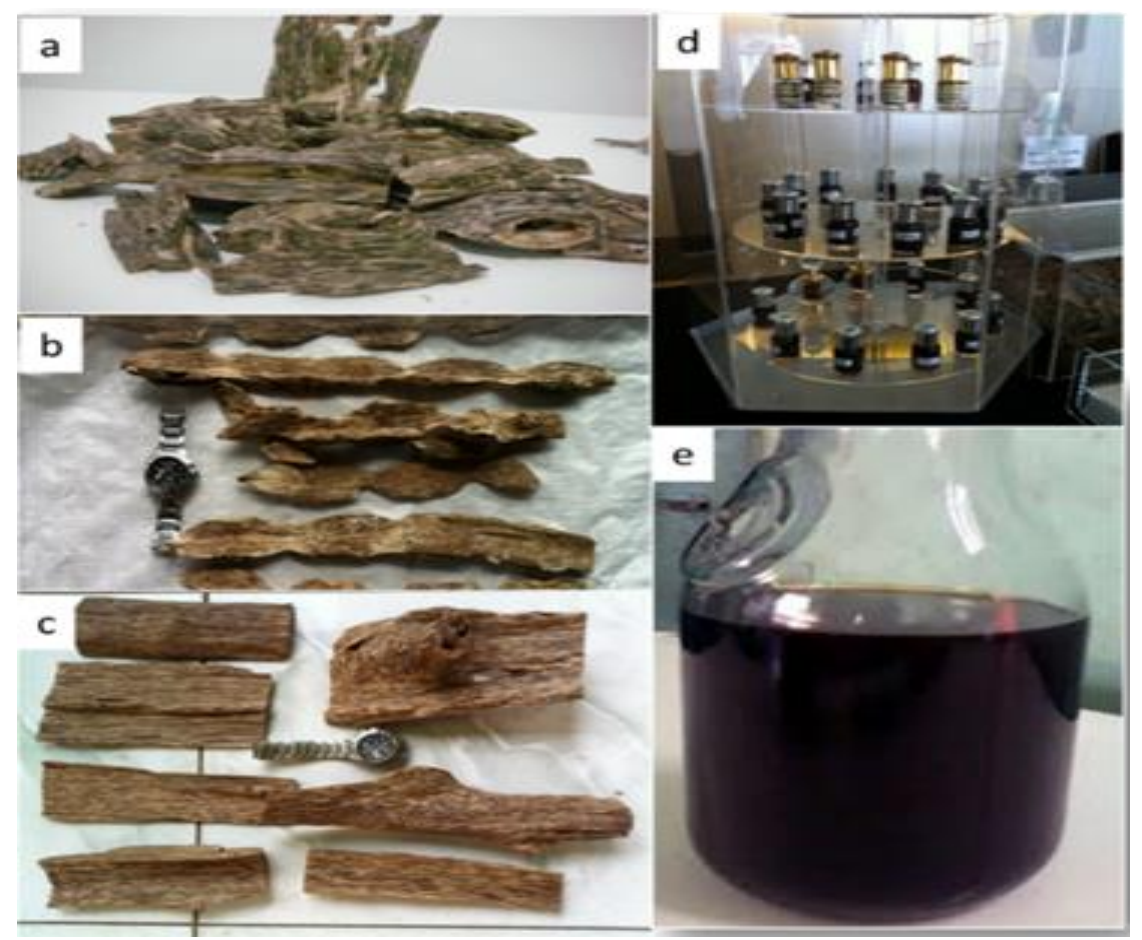

Figure 1. Aquilaria malaccensis Lam. tree (7 years old) can be harvested after three years. They are inoculated by Fusarium solani (Mart.) Sacc., producing the main products of agarwood raw materials with different grades $(\mathbf{a}-\mathbf{c})$ and agarwood oil $(\mathbf{d}, \mathbf{e})$.

Sandalwood oil has been widely used in the cologne manufacturing industry [149]. Sandalwood oil has shown various activities in animal laboratory tests. A santalum extract has displayed a spasmolytic role in digestive motility, anti-bacterial, anti-biotic, anti-inflammatory, anti-oxidant and stress-modulatory activities; and prohibited heart muscle [150-153]. Sandalwood oil is also effective for curing psoriasis, eczema, common warts, and molluscum contagiosum, as well as an anti-acne agent [154]. It is also applied in aromatherapy to ease anxiety, stress, and depression $[155,156]$. B-santalol has been found to be successful in inhibiting the replication of influenza virus A/HK (H3N2) and preventing tumor growth $[156,157]$. Sandalwood oil has been reported to have anti-inflammatory activity [158]. $\alpha$-Santalol $(10-40 \mu \mathrm{m})$ has been found to be an effective inhibitor of angiogenesis by acting on vascular endothelial growth factor (VEGF) and VEGF receptor (VEGFR2), which further inhibited the growth of prostate cancer [160]. At present, research on the anti-cancer potential of sandalwood has increased considerably [128,160,161,163,181]. It also been proven effective for treating skin papilloma and carcinoma $[127,163]$.

Since ancient times, benzoin has been used as a medicine or perfume [130]. The valuable biological activities of Styrax officinalis L. extracts have been promoted as featuring hemolytic, anti-tumor, anti-complement, anti-leukemic, anti-fungal, anti-bacterial, antioxidant, and tyrosinase inhibitory activities. Benzoin can also be directly applied to cure the throat and breathing passages of inflammation. In skincare, it kills germs, reduces swelling, and stops bleeding from minor cuts, skin ulcers, bedsores, and cracked skin. A combination of benzoin with other herbs, such as aloe, storax, and tolu balsam, is used as a skin protectant. Benzoin has also been used to treat many diseases caused by gastric acidity, chest infections, pneumonia, asthma, noisy breathing, obstructive sleep apnea, aspiration, heart failure, and cirrhosis [130,164,165]. 
Determination of the quality of cajuput oil as a product has been standardized (SNI 3954:2014) based on color, smell, specific gravity, refractive index, solubility in ethanol $80 \%$, and optical rotation. In comparison, the specific requirements, with regard to the percentage of monoterpene 1,8-cineole compound, are $>60 \%$ (super), $55 \%-60 \%$ (main), and $50 \%-55 \%$ (first) [93]. The other dominant compounds in the oils of Melaleuca leucadendron are mostly from monoterpenes, such as D-limonene, $\alpha$-terpineol, $\beta$-caryophyllene, $\alpha$-pinene, eugenol, $\beta$-pinene, globulol, $\gamma$-terpineol, $\gamma$-terpinene, 2 -pentanone, $\beta$-eudesmene, $\alpha$-humulene, and 2,4-pentanediol [135]. The dominant components of Melaleuca cajuputi oil are similar to those of Melaleuca leucadendron, but sesquiterpenes ( $\alpha$-selinene and $\alpha$-gurjunene) have additionally been detected [136].

Volatile compounds in cajuput oil, such as 1,8-cineole and $\gamma$-terpinene, are associated with its cooling aftertaste, while 1,8-cineole and caryophyllene have been linked with its sweet taste [166]. The volatile compounds of 4-terpineol, linalool, $\alpha$-terpineol, and 1,8-cineole identified in mouse blood plasma after inhalation of the cajuput oils might correlate with the content of cajuput essential oil [167]. Cajuput oil consists of menthol, which is used as an herbal treatment for abdominal pain [168]. $\alpha$-terpineol from cajuput oil showed favorable responses as an antidepressant agent [169]. Cajuput oil has displayed relatively high anti-bacterial and anti-fungal property [166,171,172].

\subsubsection{Value Chain and Product Diversification}

Processing phases change the form of the NTFPs, from the farmer to the end-user. The raw materials produced by the farmers are very diverse in form and quality. The process results in multiple value chains, involving rural labor and generating economic benefits from the farmer level to the end-user (Table 2).

Table 2. Description of the four Non-Timber Forest Products value chains.

\begin{tabular}{|c|c|c|c|c|c|c|c|}
\hline \multicolumn{2}{|c|}{$\begin{array}{c}\text { NTFPs and Commodities } \\
\text { Resulted }\end{array}$} & $\begin{array}{l}\text { Description of } \\
\text { Raw Material }\end{array}$ & $\begin{array}{l}\text { On-Farm } \\
\text { Processing }\end{array}$ & $\begin{array}{l}\text { Off-Farm } \\
\text { Processing }\end{array}$ & $\begin{array}{l}\text { Description of } \\
\text { End-Products }\end{array}$ & End-Use & References \\
\hline \multirow[t]{2}{*}{ Agarwood } & Sapwood & $\begin{array}{l}\text { Large, small } \\
\text { pieces and ash } \\
\text { of wood, } \\
\text { fragrant and } \\
\text { resinous in } \\
\text { black or brown } \\
\text { up to } 2 \mathrm{~m} \text { in } \\
\text { size }\end{array}$ & $\begin{array}{c}\text { Scraping } \\
\text { colored and } \\
\text { fragrant wood } \\
\text { from white } \\
\text { wood } \\
\text { (cleaning) }\end{array}$ & $\begin{array}{c}\text { Scraping } \\
\text { colored and } \\
\text { fragrant wood } \\
\text { from white } \\
\text { wood } \\
\text { (cleaning) } \\
\text { and/or } \\
\text { sending it into } \\
\text { chips and } \\
\text { splinters }\end{array}$ & $\begin{array}{c}\text { Agarwood ash, } \\
\text { oil-containing } \\
\text { wood }\end{array}$ & $\begin{array}{l}\text { Medicinal, } \\
\text { religious } \\
\text { rituals }\end{array}$ & {$[97,101,207]$} \\
\hline & $\begin{array}{l}\text { Agarwood } \\
\text { essential oil }\end{array}$ & $\begin{array}{l}\text { Chips } 5-10 \mathrm{~cm} \\
\text { of whitish } \\
\text { wood with } \\
\text { spots of black } \\
\text { and brown } \\
\text { colors }\end{array}$ & $\begin{array}{l}\text { Distillation of } \\
\text { essential oil }\end{array}$ & $\begin{array}{l}\text { Perfume } \\
\text { production }\end{array}$ & $\begin{array}{l}\text { Perfumes, pure } \\
\text { agarwood oil }\end{array}$ & Perfumery & \\
\hline \multirow[t]{2}{*}{ Sandalwood } & Sapwood & $\begin{array}{l}\text { Large and } \\
\text { small pieces of } \\
\text { wood }\end{array}$ & $\begin{array}{l}\text { Removing the } \\
\text { entire tree and } \\
\text { harvesting } \\
\text { wood from the } \\
\text { trunk and root }\end{array}$ & $\begin{array}{l}\text { Big chunks of } \\
\text { flakes and } \\
\text { chips }\end{array}$ & $\begin{array}{l}\text { Wood } \\
\text { Carving/ } \\
\text { Souvenir, } \\
\text { powder }\end{array}$ & Decoration & \multirow[t]{2}{*}[107,123,154,208]{} \\
\hline & $\begin{array}{l}\text { Sandalwood } \\
\text { oil }\end{array}$ & $\begin{array}{c}\text { Chips } \\
(5-10 \mathrm{~cm}) \text { of } \\
\text { woods from } \\
\text { stump and root }\end{array}$ & $\begin{array}{l}\text { Distillation of } \\
\text { essential oil }\end{array}$ & $\begin{array}{l}\text { Packaging } \\
\text { Perfume } \\
\text { production }\end{array}$ & $\begin{array}{l}\text { High quality } \\
\text { perfumes }\end{array}$ & $\begin{array}{l}\text { Perfumery, } \\
\text { medicinal, } \\
\text { religious } \\
\text { rituals }\end{array}$ & \\
\hline Cajuput & $\begin{array}{c}\text { Cajuput } \\
\text { essential oil }\end{array}$ & $\begin{array}{l}\text { Leaves and } \\
\text { twigs }\end{array}$ & $\begin{array}{c}\text { Collecting } \\
\text { leaves and } \\
\text { twigs }\end{array}$ & $\begin{array}{c}\text { Distillation of } \\
\text { essential oil }\end{array}$ & $\begin{array}{l}\text { Pure Cajuput } \\
\text { Oil }\end{array}$ & $\begin{array}{l}\text { Medicinal, } \\
\text { aromatherapy }\end{array}$ & {$[79,187]$} \\
\hline & & Resin & $\begin{array}{l}\text { Scrapping the } \\
\text { resin from the } \\
\text { bark, collecting } \\
\text { the resin with } \\
\text { the bark pieces }\end{array}$ & $\begin{array}{l}\text { Distillation of } \\
\text { essential oil }\end{array}$ & $\begin{array}{l}\text { Benzoin } \\
\text { essential oil }\end{array}$ & $\begin{array}{l}\text { Medicinal, } \\
\text { perfumery }\end{array}$ & {$[88,89,130]$} \\
\hline
\end{tabular}


Generally, agarwood is transformed in various product derivatives [97]. The wood is sometimes chopped into sticks or splinters without any further processing, to be used as a fragrance in incense that is a high-valued perfumery raw material, surpassing the value of gold [197]. Sandalwood oil is also used in stick incense products, incense cones, soaps, and creams/lotions. Other products made from sandalwood are statues/carvings and sandalwood bracelets/prayer beads. Sandalwood oil is the most common product. Sandalwood oil packaged in glass bottles costs around IDR $150,000 / 15 \mathrm{~mL}$ to IDR $850,000 / 3 \mathrm{~mL}$.

One of the most well-known sandalwood derivative products is incense (i.e., stick and cone incense). In Indonesia, cone-shaped sandalwood incense is sold at a minimum of IDR 22,500/jar (70 cones) or IDR 15,000/pack (8 sticks). Deodorant cream created from a mixture of aluminum sulfate and sandalwood essential oil is non-irritating and provides comfort [173]. Sandalwood cream/lotion is sold at around IDR 3000/150 mL. Sandalwood oil can be used as a soap additive [104]. In Indonesia, sandalwood soap is sold for around IDR $5000 / 81 \mathrm{~g}$ to IDR $13,000 / 125 \mathrm{~g}$.

Sumatran benzoin has mainly used for incense purposes [134] in the past. Recently, it has been expanded to be utilized in the fragrance industry (Figure 2) as a fixative agent for anti-aging purposes, and as food flavoring [129]. Benzoin oil is also processed into a perfume base-note [89]. Furthermore, benzoin has also been employed as a hair growth and blackening agent. It also has medicinal properties to reduce fever, relieve itching on the skin, and can be used as a liniment or massage oil [105]. The highest price of raw resin at local traders reaches IDR 250,000-290,000/ $\mathrm{kg}$ for the highest grade and IDR 50,000 to 75,000 for the lowest grades. The benzoin oil resulting from the distillation process has a higher economic value, ranging from IDR 5 to 7 million/liter. The value-added can reach four times higher than that of the raw resin [89].
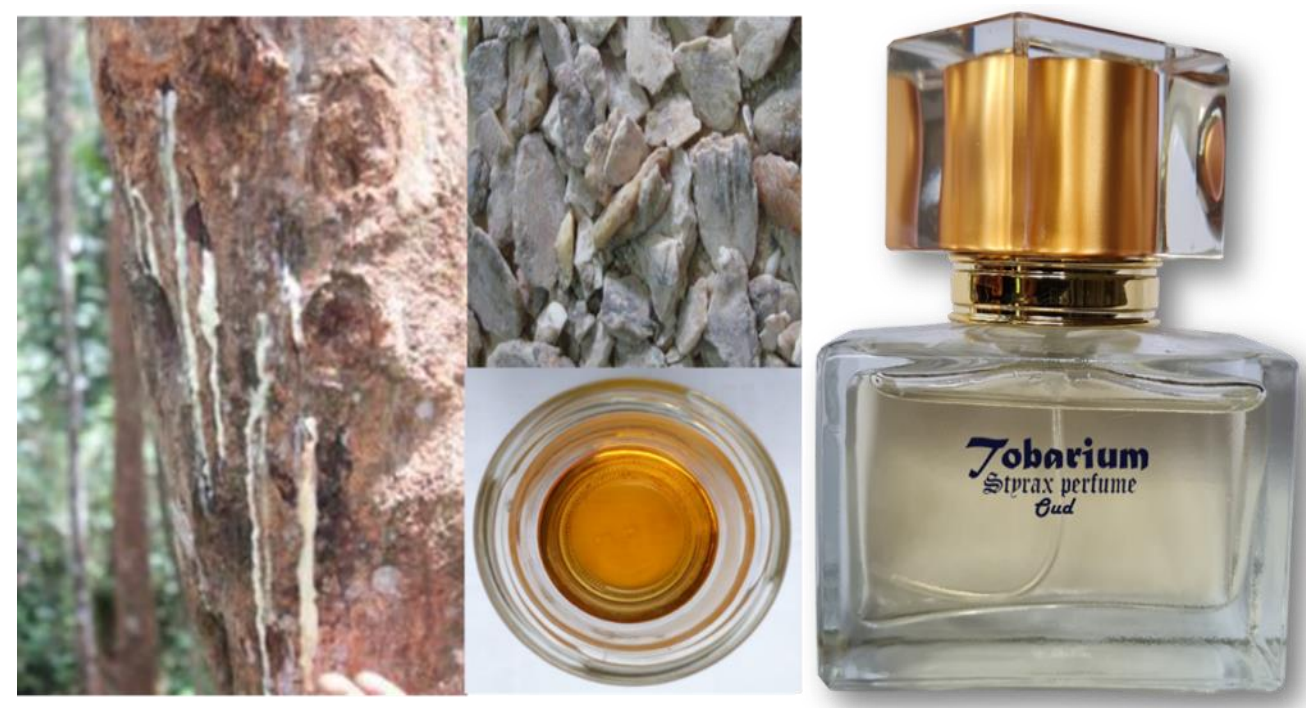

Figure 2. Resin processing and product innovation of benzoin.

Cajuput oil is the main product of cajuput, which is used in incense sticks, soaps, creams/lotions, candies, and the middle layer of three-layer masks (Figure 3). Other products from cajuput leaves are herbal teas and sponge cakes. Cajuput oil is sold from IDR $5000 / 15 \mathrm{~mL}$ to IDR $40,000 / 120 \mathrm{~mL}$ in plastic bottles. In comparison, cajuput oil packaged in glass bottles costs around IDR 250,000/350 mL. Based on the 48th International Fragrance Association (IFRA) 2015, incense is a cajuput oil product that does not contact the skin directly. Incense with the cajuput oil aroma that can burn for $12 \mathrm{~h}$ is sold at IDR 25,000/pack ( 3 sticks) in online stores. Cajuput oil incense tends to have an oily surface and is more difficult to burn. Cajuput oil is a scented aroma agent in soaps [130]. Cajuput soaps are sold for IDR 8500/160 $\mathrm{g}$ in the online market. 


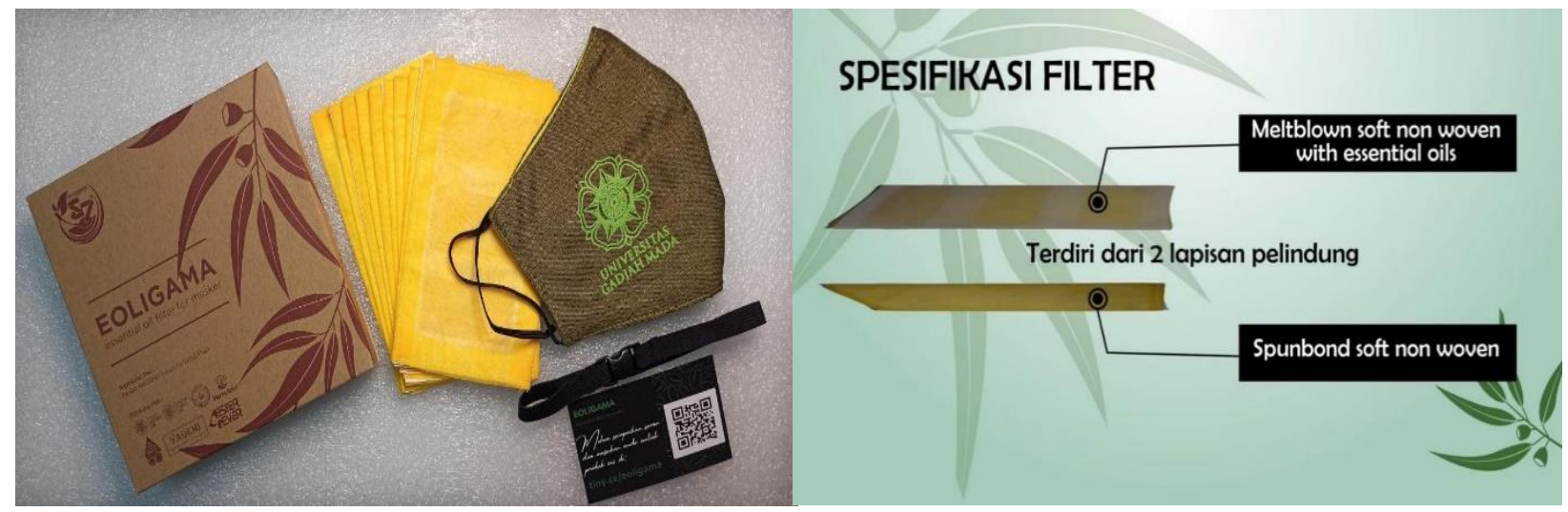

Figure 3. Cajuput essential oil filter for face mask.

One of the "ArthroSoothe" cream ingredients that can be used to moisturize the skin is cajuput oil. In Indonesia, cajuput cream is sold from IDR 9000-15,000 per pack. Cajuput oil has also been used in lotion products. Other product innovations are sucrose and non-sucrose cajuput candies, which have been produced since 1997 in Indonesia, to add the economic values of cajuput oil [180]. The candies are priced as much as IDR $70,000-125,000 / \mathrm{kg}$. Cajuput candy inhibits Candida albicans and Streptococcus mutans during the development of dental caries [166].

\section{Challenges and Prospects}

In general, propagation materials for NTFPs species rely on natural regeneration, except for cajuput, which has been mass-propagated both generatively and vegetatively to meet the high demands of large-scale plantation to produce commercial essential oil $[177,187]$. Preparation for agarwood seeding is conducted by sowing abundant seeds from the mother trees, which bear fruit in two periods: May-June and January-February. However, seed collection requires special preparation for climbing the mother trees and precise information about the ripeness of the fruit. Therefore, farmers are more likely to collect several young wild seedlings $(5-10 \mathrm{~cm})$ which germinate around the mother trees, then transfer them to polybags and maintain them until they are ready to be planted in the field [34]. Relatively similar conditions also occur for the preparation of plant materials of benzoin and sandalwood tree species. Despite the selection conducted, the propagation of benzoin-producing trees in cultivation centers in North Sumatra still relies on natural regeneration [106]. Only the best-growing plants around the highest productivity mother trees are maintained and nurtured. To date, efforts to develop mother trees with the best phenotypes are still limited. Fortunately, despite the small and limited scale, several vegetative propagation attempts of mother trees from various provenances in North Sumatra have shown great potential and prospects for wide-scale development in the future [188]. Meanwhile, cajuput populations in natural distribution are becoming scarce due to unsustainable leaf-harvesting practices. The local people stimulate the growth new shoots and leaves growth by burning cajuput stands. Due to these repeated fires, the main stem is vulnerable to death $[177,187]$.

Like most forest tree species, seed propagation has also become a standard for these four aromatic species. However, their populations have tended to dramatically decline, as worsened by some difficulties in propagating through conventional procedures. Several vegetative propagation techniques have also been adopted and, recently, in vitro techniques using various types of concentration ratios of growth regulators have been found to be more effective for mass reproduction [108,189].

As an example of a success story for the local community in sandalwood, cultivation has encouraged the local government to include sandalwood development through social forestry programs (Figure 4). This scheme is expected to increase sandalwood planting 
inside and outside the forest area in Eastern Indonesia. In addition, climate change and rainfall intensity is expected to affect the sandalwood phenology [190,191].
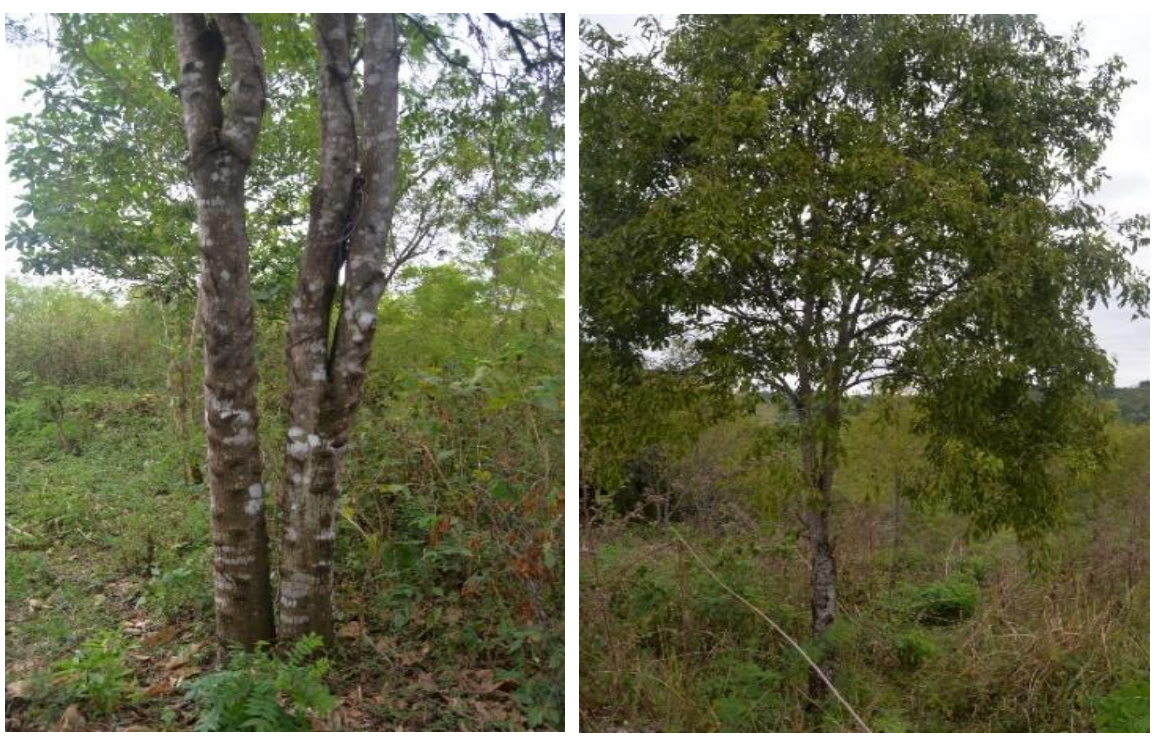

Figure 4. Natural regeneration of sandalwood on private land around the settlement of local communities in Sumba.

Most agarwood comes from natural forests, but some valuable commodities are managed on private lands or community forests, in order to protect assets for security reasons in the long-term. Since the 2000s, around 3.5 million agarwood-producing trees, including Aquilaria and Gyrinops species, have been planted in community forests or gardens throughout Indonesia [34] (see Figure 5).

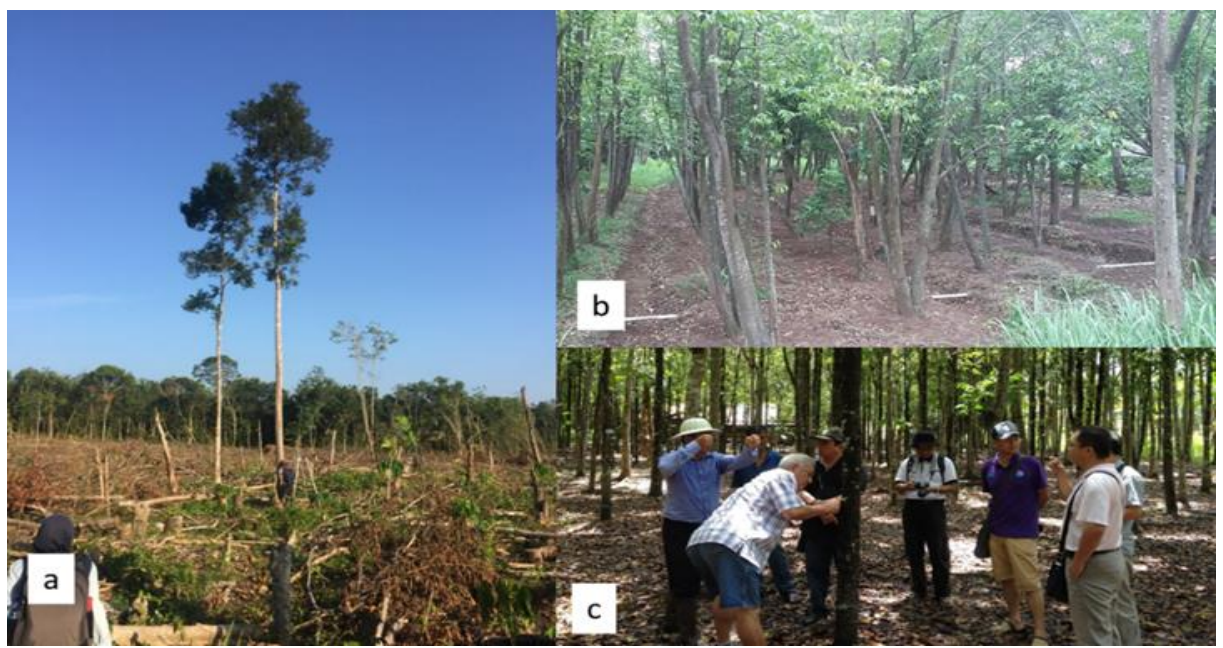

Figure 5. The population of natural agarwood producing trees has decreased, and they have been substituted by agarwood plantations in Indonesia: (a) Natural Aquilaria malaccensis in South Sumatera; (b) Aquilaria malaccensis plantation in Banten Province; and (c) Aquilaria microcarpa plantation in West Kalimantan.

As a cultivated plant, agarwood production faces some challenges, including the inoculation process, which requires an effective fungal species for agarwood formation [109-111]. In addition, the inoculum practice at a large scale requires high-quality agarwood-forming inoculants and skilled labor. Based on several inoculation tests, some candidate fungi have been identified, as shown in Table 3. 
Table 3. Some endophyte fungi species were utilized in agarwood formation production.

\begin{tabular}{|c|c|c|c|}
\hline Endophytic Fungi & $\begin{array}{l}\text { Agarwood Tree } \\
\text { Species }\end{array}$ & Success Rate & References \\
\hline \multirow{6}{*}{ Fusarium solani } & Aquilaria malaccensis Lamk. & high & {$[34,110,178,179,192]$} \\
\hline & Aquilaria macrocarpa Baill & moderate & {$[209,210]$} \\
\hline & Aquilaria beccariana van Tiegh & high & [211] \\
\hline & Aquilaria cumingiana (Decne.) Ridley & high & [192] \\
\hline & Aquilaria crassna Pierre ex Lecomte & high & [212] \\
\hline & Gyrinops versteegii (Gilg.) Domke & high & {$[178,179]$} \\
\hline \multirow{2}{*}{ Fusarium xylaroides } & Aquilaria malaccensis Lamk & high & [192] \\
\hline & Aquilaria macrocarpa Baill & moderate & [192] \\
\hline \multirow{2}{*}{ Acremonium sp. } & Aquilaria malaccensis Lamk & moderate & [213] \\
\hline & Gyrinops caudata (Gilg.) Domke & moderate & [214] \\
\hline Trichoderma sp. & Gyrinops versteegii (Gilg.) Domke & moderate & [215] \\
\hline Rhizopus sp. & Gyrinops versteegii (Gilg.) Domke & moderate & [215] \\
\hline Aspergillus sp. & Aquilaria sp. & moderate & [216] \\
\hline Penicillium sp. & Aquilaria sp. & moderate & [216] \\
\hline
\end{tabular}

Remark: Success rate is categorized as high $(90 \%-100 \%)$, moderate $(60 \%-89 \%)$, or low $(<59 \%)$.

As a semi-tolerant species, agarwood-producing trees need shade at the beginning of their growth. In this case, an agroforestry system that combines agarwood with rubber trees can be developed. Further, the combination of agarwood, shade trees, and horticultural crops (e.g., vegetables) can result in complex agroforest systems on limited land [192]. The trees can also possibly be planted in the yard (home garden). Planting in the garden around the residences makes them easy to monitor for safety, inoculation, and harvesting [34].

Benzoin development has shown high potential, regarding its cultivation history, and is closely linked with the livelihood of communities. Nevertheless, benzoin tree cultivation is subsistence and sub-optimal, characterized by traditional, low processing techniques and limited product diversification with high economic value. There are no appropriate processing technologies that inhibit benzoin oil industry development or affect benzoin forest management in the long-term $[88,217]$. Sub-optimal conditions also refer to the management of stands that do not reflect the normality of growth and yield; for example, individual growth and resin productivity are still below average, due to still relying on natural regeneration and limited efforts to develop seeds from breeding. Therefore, appropriate strategies can be implemented by accelerating the development of superior seed sources and in situ/ex situ genetic conservation to reduce genetic depletion. Research on seed technology is needed to increase germination; a crucial aspect is the superiority of developing seeds through phenological [188] and ecological observations [106], as well as collection of genetic material from various provenances and the development of superior mother trees [218]. The development of provenance stands can be used as an initial breeding strategy to obtain superior benzoin seeds and genetic conservation [219].

The key to the sustainability of agarwood production is cultivation activities in the form of mass-scale plantings. Indonesia has various agarwood-producing tree species that have a comparative advantage. Efforts to collect various genotypes in seed or clonal orchards must be carried out for further breeding and tree improvement. Cultivation, especially in the private sector, practically does not exist in Indonesia. Private businesses are still focused on natural agarwood products. At present, there exist about 40 companies that collect and export natural agarwood to various countries. Cultivation that takes a long time from planting to harvesting-at least ten years-has been identified as the cause of the problem. However, other ASEAN countries, including Malaysia, Thailand, Myanmar, Cambodia, Lao PRD, and Vietnam, have planted many trees involving the business sector. In these countries, agarwood oil is the main product, while agarwood sapwood is processed for incense.

To sustain the global agarwood supply, Indonesia must begin increasing the number of cultivated agarwood plantations and products through mass-scale planting activities and 
the inoculation of agarwood. The world market requires low-grade agarwood products for medicinal purposes, accessories for many religions, and perfumes (Table 4).

Table 4. Distribution of agarwood producers and consumers.

\begin{tabular}{ccc}
\hline Species & Major Producing Countries & $\begin{array}{c}\text { Major Consumer } \\
\text { Countries }\end{array}$ \\
\hline A. crassna & Cambodia, Laos, Thailand, Vietnam & $\begin{array}{c}\text { Middle East, Japan } \\
\text { China, Japan }\end{array}$ \\
A. sinensis & China & Middle East \\
A. malaccensis & Malaysia, India, Myanmar, Indonesia, Philippines & Middle East \\
A. filaria & Indonesia, Philippines & Middle East \\
A. hirta & Indonesia, Malaysia & Middle East \\
A. microcarpa & Malaysia, Indonesia & Middle East \\
A. beccariana & Malaysia, Indonesia & Middle East \\
A. cumingiana & Indonesia & Middle East, China \\
G. versteegii & Indonesia, Papua New Guinea & Middle East, China \\
G. caudata & Indonesia, Papua New Guinea & Middle East, China \\
G. moluccana & Indonesia, Papua New Guinea & Middle East \\
G. walla & Sri Lanka & \\
\hline
\end{tabular}

Furthermore, the sustainability of sandalwood management is determined by the collaboration of both the local governments, community, and the private sector, especially in planting development on owned-land and forest areas. Integrating sandalwood-based commodities in social forestry programs using agroforestry systems [99] provides an opportunity to increase community participation in the plantation in forest areas, especially in the 2308 villages both in and around the forest in the NTT Province [220]. The local government's campaign for sandalwood conservation requires increasing the tree population in the natural habitats and encourages the participation of multiple stakeholders, such as schools, offices, community leaders, religious institutions, NGOs, and public organizations. The government has funded the development of millions of sandalwood trees in recent years due to their commitment to restoring their population, production, and sustainability. Breakthroughs in sandalwood development by the local government need to be in balance with planned and measured maintenance [221], in order to improve the quality and quantity of sandalwood production. In addition, attention to seed sources and habitats that support the proper growth and development of sandalwood is needed [191], primarily to support the success of sandalwood cultivation.

\section{Conclusions}

In this study, we reviewed the challenges and prospects of four essential aromatic NTFPs species in Indonesia. The forest-dwellers utilizing NTFPs such as agarwood, benzoin, sandalwood, and cajuput, have lasted centuries across generations. However, NTFPs regulations have not yet been established for good governance implementation; that is, the value chain of NTFPs to the farmers (as producers) has not been sufficiently strengthened, adaptive management has not been properly implemented, farmer-economic institutions have not been facilitated, trade and market information has not been enhanced, floor prices have not been set, appropriate incentives are not yet provided, and cross-sectoral coordination remain to be improved. Regarding the marketing system, the middle-man wholesalers still dominate the current marketing information and pricing. Increasing international demand for NTFPs products has led to over-exploitation of the NTFPs, especially natural agarwood and sandalwood. Uncontrolled harvesting of NTFPs will result in the unsustainability of these resources. The cultivation systems for agarwood, benzoin, and sandalwood are still traditional, calling for the application of better silviculture technology. On the other hand, cajuput has been cultivated with a better system. Research and development into cultivation technology is necessary, in order to improve all NTFPs plantations. Harvesting and processing of the products still rely on traditional techniques and local knowledge, as some existing technological innovations do not significantly increase the yield or quality. 
The government needs to improve the governance of NTFPs, starting from the system of cultivation, harvesting, processing, and marketing, such that the abundance of NTFPs in Indonesia can sustainably improve the welfare of communities.

Author Contributions: All authors made equal contributions to resources, conceptualization, methodology, analysis, validation, writing, review, and editing of the manuscript. All authors have read and agreed to the published version of the manuscript.

Funding: This research was partly supported by Center for Standardization of Environmental Quality Instruments, Ministry of Environment and Forestry of the Republic of Indonesia through annual budget Number SP DIPA-029.07.1.403439/2021.

Acknowledgments: We would like to thank Center for Standardization of Environmental Quality Instruments, Ministry of Environment and Forestry of the Republic of Indonesia for providing financial support for this paper.

Conflicts of Interest: The authors declare no conflict of interest.

\section{References}

1. Government of Indonesia. Statistik 2019 Kementerian Lingkungan Hidup dan Kehutanan; Mochtar, M., Rahman, T., Lukmansjah, D., Eds.; Kementerian Kehutanan dan Lingkungan Hidup RI: Jakarta, Indonesia, 2020.

2. De Mello, R.N.G.; Gulinck, H.; Broeck, V.; Parra, C. Social-ecological sustainability of non-timber forest products: A review and theoretical considerations for future research. For. Policy Econ. 2020, 112, 102109. [CrossRef]

3. Government of Indonesia. Peraturan Menteri Kehutanan Nomor: P.35/Menhut-II/2007 Tentang Hasil Hutan Bukan Kayu; Government of Indonesia: Jakarta, Indonesia, 2007; p. 24.

4. Hadiyane, A.; Sulistyawati, E.; Asharina, W.P.; Dungani, R. A study on production of resin from Pinus merkusii Jungh. Et De Vriese in the Bosscha Observatory Area, West Java-Indonesia. Asian J. Plant Sci. 2015, 14, 89-93. [CrossRef]

5. Adam, Y.O.; Pretzsch, J.; Pettenella, D. Contribution of non-timber forest products livelihood strategies to rural development in drylands of Sudan: Potentials and failures. Agric. Syst. 2013, 117, 90-97. [CrossRef]

6. Heubach, K.; Wittig, R.; Nuppenau, E.A.; Hahn, K. The economic importance of Non-Timber Forest Products (NTFPs) for livelihood maintenance of rural west African communities: A case study from northern Benin. Ecol. Econ. 2011, 70, 1991-2001. [CrossRef]

7. Schaafsma, M.; Morse-Jones, S.; Posen, P.; Swetnam, R.D.; Balmford, A.; Bateman, I.J.; Burgess, N.D.; Chamshama, S.A.O.; Fisher, B.; Freeman, T.; et al. The importance of local forest benefits: Economic valuation of non-timber forest products in the eastern Arc mountains in Tanzania. Glob. Environ. Chang. 2014, 24, 295-305. [CrossRef]

8. Shackleton, C.M.; Pandey, A.K. Positioning Non-Timber Forest Products on the development agenda. For. Policy Econ. 2014, 38, 1-7. [CrossRef]

9. Kurniasih, H.; Ford, R.M.; Keenan, R.J.; King, B. The evolution of community forestry through the growth of interlinked community institutions in Java, Indonesia. World Dev. 2021, 139, 105319. [CrossRef]

10. Živojinović, I.; Nedeljković, J.; Stojanovski, V.; Japelj, A.; Nonić, D.; Weiss, G.; Ludvig, A. Non-timber forest products in transition economies: Innovation cases in selected SEE countries. For. Policy Econ. 2017, 81, 18-29. [CrossRef]

11. Harbi, J.; Erbaugh, J.T.; Sidiq, M.; Haasler, B.; Nurrochmat, D.R. Making a bridge between livelihoods and forest conservation: Lessons from non timber forest products' utilization in South Sumatera, Indonesia. For. Policy Econ. 2018, 94, 1-10. [CrossRef]

12. Guariguata, M.R.; García-Fernández, C.; Sheil, D.; Nasi, R.; Herrero-Jáuregui, C.; Cronkleton, P.; Ingram, V. Compatibility of timber and Non-Timber Forest Products management in natural tropical forests: Perspectives, challenges, and opportunities. For. Ecol. Manag. 2010, 259, 237-245. [CrossRef]

13. Lopes, E.; Soares-Filho, B.; Souza, F.; Rajão, R.; Merry, F.; Carvalho Ribeiro, S. Mapping the socio-ecology of non-timber forest products (NTFP) extraction in the Brazilian Amazon: The case of açaí (Euterpe precatoria Mart) in Acre. Landsc. Urban Plan. 2019, 188, 110-117. [CrossRef]

14. Delgado, T.S.; McCall, M.K.; López-Binqüist, C. Recognized but not supported: Assessing the incorporation of Non-Timber Forest Products into Mexican forest policy. For. Policy Econ. 2016, 71, 36-42. [CrossRef]

15. Chavan, S.B.; Uthappa, A.R.; Sridhar, K.B.; Keerthika, A.; Handa, A.K.; Newaj, R.; Kumar, N.; Kumar, D.; Chaturvedi, O.P. Trees for life: Creating sustainable livelihood in Bundelkhand region of central India. Curr. Sci. 2016, 111, 994-1002. [CrossRef]

16. Bannor, R.K.; Ros-Tonen, M.A.F.; Mensah, P.O.; Derkyi, M.; Nassah, V.F. Entrepreneurial behaviour among Non-timber forest products growing farmers in Ghana: An analysis in support of a reforestation policy. For. Policy Econ. 2021, 122, 102331. [CrossRef]

17. Sisak, L.; Riedl, M.; Dudik, R. Non-market non-timber forest products in the Czech Republic their socio-economic effects and trends in forest land use. Land Use Policy 2016, 50, 390-398. [CrossRef]

18. Nguyen, T.V.; Lv, J.H.; Ngo, V.Q. Factors determining upland farmers' participation in non-timber forest products value chains for sustainable poverty reduction in Vietnam. For. Policy Econ. 2021, 126, 102424. [CrossRef]

19. Schmidt, L.; Widianingsih, N.N.; Kaad, A.P.; Theilade, I. The impact of deforestation on collection and domestication of Jernang (Daemonorops spp.) and other NTFPs in southern Sumatra, Indonesia. NJAS Wagening. J. Life Sci. 2020, 92, 100325. [CrossRef] 
20. Weiss, G.; Hansen, E.; Ludvig, A.; Nybakk, E.; Toppinen, A. Innovation governance in the forest sector: Reviewing concepts, trends and gaps. For. Policy Econ. 2021, 130, 102506. [CrossRef]

21. Epanda, M.A.; Donkeng, R.T.; Nonga, F.N.; Frynta, D.; Adi, N.N.; Willie, J.; Speelman, S. Contribution of non-timber forest product valorisation to the livelihood assets of local people in the northern periphery of the Dja Faunal Reserve, East Cameroon. Forests 2020, 11, 1019. [CrossRef]

22. Kuncoro, M.; Cahyani, D. Performance of social forestry on farmers' revenues: Lessons from Yogyakarta and Lampung, Indonesia. Bus. Manag. Rev. 2018, 9, 275-289.

23. Großmann, K. Gaharu King-Family Queen: Material gendered political ecology of the eaglewood boom in Kalimantan, Indonesia. J. Peasant Stud. 2017, 44, 1275-1292. [CrossRef]

24. Zenteno, M.; Zuidema, P.A.; de Jong, W.; Boot, R.G.A. Livelihood strategies and forest dependence: New insights from Bolivian forest communities. For. Policy Econ. 2013, 26, 12-21. [CrossRef]

25. Sayer, J.; Boedhihartono, A.K.; Langston, J.D.; Margules, C.; Riggs, R.A.; Sari, D.A. Governance challenges to landscape restoration in Indonesia. Land Use Policy 2021, 104. [CrossRef]

26. Zhu, Y.; Fu, B.; Liu, J.; Wang, Y.; Xu, P.; Yan, K.; Li, M.; Liu, Q. Sale of wild edible fungi-Key influence on the relationship between household livelihood and non-timber forest products utilisation: A case study in the three gorges reservoir area. For. Ecol. Manag. 2019, 444, 1-8. [CrossRef]

27. Kamwi, J.M.; Endjala, J.; Siyambango, N. Dependency of rural communities on non-timber forest products in the dry lands of southern Africa: A case of Mukwe Constituency, Kavango East Region, Namibia. Trees For. People 2020, 2, 100022. [CrossRef]

28. Azhar, I.; Chandra, R.; Aulin, F.R.; Risnasari, I. Marketing strategy for kemenyan (Styrax spp.) by community around the protected area HPHTI of PT. Toba Pulp Lestari. J. Phys. Conf. Ser. 2020, 1542, 012028. [CrossRef]

29. Myers, R.; Intarini, D.; Sirait, M.T.; Maryudi, A. Claiming the forest: Inclusions and exclusions under Indonesia's 'new' forest policies on customary forests. Land Use Policy 2017, 66, 205-213. [CrossRef]

30. Asif, M.; Saleem, M.; Saadullah, M.; Yaseen, H.S.; Zarzour, R. Al COVID-19 and therapy with essential oils having antiviral, anti-inflammatory, and immunomodulatory properties. Inflammopharmacology 2020, 28, 1153-1161. [CrossRef] [PubMed]

31. Hanson, J.R. Natural Products: The Secondary Metabolites; Abel, E.W., Davies, A.G., Philips, D., Woolins, J.D., Eds.; Royal Society of Chemistry: Cambridge, UK, 2003.

32. Sindhu, S.M. Editorial note on importance of essential oils. Med. Aromat. Plants 2020, 9, 1-2. [CrossRef]

33. Irshad, M.; Subhani, M.A.; Ali, S.; Hussain, A. Biological importance of essential oils. In Essential Oils-Oils of Nature; Books on Demand: Norderstedt, Germany, 2019; Volume 1, pp. 1-15.

34. Turjaman, M.; Hidayat, A. Agarwood-planted tree inventory in Indonesia. In Proceedings of the IOP Conference Series: Earth and Environmental Science, Prague, Czech Republic, 11-15 September 2017.

35. Turjaman, M.; Hidayat, A.; Santoso, E. Development of agarwood induction technology using endophytic fungi. In Agarwood: Science Behind the Fragrance; Rozi, M., Ed.; Springer: Singapore, 2016; pp. 57-71.

36. Statistical Bureau of North Sumatra Province. Provinsi Sumatera Utara Dalam Angka 2021; Statistical Bureau of North Sumatra Province: North Sumatra, Indonesia, 2021.

37. Ambarita, E.C.; Sitorus, H. Modal sosial komunitas petani kemenyan dalam pelestarian hutan kemenyan di Desa Pandumaan, Kecamatan Pollung, Kabupaten Humbang Hasundutan. Perspekt. Sosiol. 2014, 3, 42-57.

38. Lumban Gaol, S.B.M.; Yoza, D.; Arlita, T. Analisis pemasaran kemenyan (Styrax spp.) di Desa Simarigung (studi kasus di Desa Simarigung, Kec. Dolok Sanggul, Kab. Humbang Hasundutan). Peronema For. Sci. J. 2012, 1, $39-45$.

39. Marwati Sandalwood in Indonesia Threatened to Extinction. Available online: https://www.ugm.ac.id/en/news/14977sandalwood-in-indonesia-threatened-to-extinction (accessed on 1 September 2021).

40. Rohadi, D.; Maryani, R.; Widyana, M.; Azhar, I. A case study of the production- to-consumption system of sandalwood (Santalum album) in South Central Timor. For. Prod. Livelihoods Conserv. 2004, 1, 183.

41. Kurniawan, H.; Pamungkas, D. The limiting factors of land suitability for sandalwood (Santalum album) in Sumba island, Indonesia. Biodiversitas 2020, 21, 3364-3372. [CrossRef]

42. Alu, A.K.; Rusli, M.S. Formulating strategies for improving the competitiveness of cajuput small industry in Buru Regency's (a case study). In Proceedings of the Brawijaya International Conference on Multidisciplinary Sciences and Technology Formulating, Jawa Timur, Indonesia, 2-3 January 2020; Volume 456, pp. 72-75.

43. My, T.T.A.; Loan, H.T.P.; Hai, N.T.T.; Hieu, L.T.; Hoa, T.T.; Thuy, B.T.P.; Quang, D.T.; Triet, N.T.; Van Anh, T.T.; Dieu, N.T.X.; et al. Evaluation of the inhibitory activities of COVID-19 of Melaleuca cajuputi oil using docking simulation. ChemistrySelect 2020, 5, 6312-6320. [CrossRef] [PubMed]

44. Meinhold, K.; Darr, D. The processing of non-timber forest products through small and medium enterprises-A review of enabling and constraining factors. Forests 2019, 10, 1026. [CrossRef]

45. Moradi, S.; Limaei, S.M.; Lohmander, P.; Khanmohammadi, M. Quantitative and financial evaluation of non-timber forest products (case study: Zemkan basin forests, West of Iran). J. For. Res. 2017, 28, 371-379. [CrossRef]

46. Miina, J.; Kurttila, M.; Calama, R.; De-Miguel, S.; Pukkala, T. Modelling Non-timber Forest Products for forest management planning in Europe. Curr. For. Rep. 2020, 6, 309-322. [CrossRef]

47. Wahyudi, W. Non-Timber Forest Product (Ntfp) commodities harvested and marketed by local people at the local markets in Manokwari-West Papua. Indones. J. For. Res. 2017, 4, 27-35. [CrossRef] 
48. Shanley, P.; Pierce, A.R.; Laird, S.A.; Binnquist, C.L.; Guarigata, M.R. From Lifelines to Livelihoods: Non-Timber Forest Products into the 21st Century, 2016th ed.; Pancel, L., Kohl, M., Eds.; Springer: Berlin, Germany, 2016; Volume 1, ISBN 9783642546013.

49. Dawson, I.K.; Leakey, R.; Clement, C.R.; Weber, J.C.; Cornelius, J.P.; Roshetko, J.M.; Vinceti, B.; Kalinganire, A.; Tchoundjeu, Z.; Masters, E.; et al. The management of tree genetic resources and the livelihoods of rural communities in the tropics: Non-timber forest products, smallholder agroforestry practices and tree commodity crops. For. Ecol. Manag. 2014, 333, 9-21. [CrossRef]

50. Zhu, H.; Hu, S.; Ren, Y.; Ma, X.; Cao, Y. Determinants of engagement in non-timber forest products (NTFPs) business activities: A study on worker households in the forest areas of Daxinganling and Xiaoxinganling Mountains, northeastern China. For. Policy Econ. 2017, 80, 125-132. [CrossRef]

51. Wong, G.; Greenhalgh, T.; Westhorp, G.; Buckingham, J.; Pawson, R. RAMESES publication standards: Meta-narrative reviews. J. Adv. Nurs. 2013, 69, 987-1004. [CrossRef]

52. Broekhoven, G.; Savenije, H.; von Scheliha, S. Moving Forward with Forest Governance; Tropenbos International: Wageningen, The Netherlands, 2012; ISBN 9789051131079.

53. Budiman, I.; Fujiwara, T.; Sato, N.; Pamungkas, D. Another law in Indonesia: Customary land tenure system coexisting with State Order in Mutis Forest. J. Manaj. Hutan Trop. 2020, 26, 244. [CrossRef]

54. Friedman, R.S.; Guerrero, A.M.; McAllister, R.R.J.; Rhodes, J.R.; Santika, T.; Budiharta, S.; Indrawan, T.; Hutabarat, J.A.; Kusworo, A.; Yogaswara, H.; et al. Beyond the community in participatory forest management: A governance network perspective. Land Use Policy 2020, 97, 104738. [CrossRef]

55. Begemann, A.; Giessen, L.; Roitsch, D.; Roux, J.L.; Lovrić, M.; Azevedo-Ramos, C.; Boerner, J.; Beeko, C.; Cashore, B.; Cerutti, P.O.; et al. Quo vadis global forest governance? A transdisciplinary delphi study. Environ. Sci. Policy 2021, 123, 131-141. [CrossRef]

56. Subekti, R.; Wawo, A.H.; van Noordwijk, M.; Hairiah, K. Cendana, Deregulasi dan Strategi Pengembangannya, 1st ed.; ICRAF: Bogor, Indonesia, 2002.

57. McWilliam, A. Haumeni, not many: Renewed plunder and mismanagement in the timorese sandalwood industry. Mod. Asian Stud. 2005, 39, 285-320. [CrossRef]

58. Raharjo, S.A.S.; Awang, S.A.; Pramusinto, A.; Purwanto, R.H. Sejarah dominasi negara dalam pengelolaan cendana di Nusa Tenggara Timur. J. Mns. Lingkung. 2013, 20, 1-10.

59. Ardhana, I.K. Penataan Nusa Tenggara Pada Masa Kolonial 1915-1990; Rajawali Pers, Sosiologi dan Politik: Jakarta, Indonesia, 2006.

60. Azhari, I. "Politik Historiografi" sejarah ldkal: Kisah kemenyan dan kapur dari Barus, Sumatera Utara. Sej. Budaya J. Sej. Budaya Pengajarannya 2017, 11, 9-23. [CrossRef]

61. Karim, A. Daryanto Perlindungan hukum dan pengembangan potensi indikasi geografis minyak kayu putih Pulau Buru. J. Rechtsvinding 2016, 5, 381-398.

62. Directorate General of Intellectual Property Geographical Indication. Available online: https://www.dgip.go.id/menu-utama/ indikasi-geografis / pengenalan (accessed on 21 September 2021).

63. Surata, I.K.; Idris, M.M. Status penelitian cendana di Provinsi Nusa Tenggara Timur. Ilm. Ber. Biol. $2001,5,521-537$.

64. Applegate, G.B.; Chamberlain, J.; Daruhi, G.; Feigelson, J.L.; Hamilton, L.; McKinnell, F.H.; Neil, P.E.; Rai, S.N.; Rodehn, B.; Stemmermann, L. Sandalwood in the Pacific: A state of knowledge synthesis and summary from the April 1990 symposium. In Proceedings of the Symposium on Sandalwood in the Pacific, Honolulu, HI, USA, 9-11 April 1990; pp. 1-11.

65. Harianja, A.H. Pengelolaan Hutan Kemenyan di Sumatera Utara: Analisis Sosial, Ekonomi, Silvikultur dan Ekologi; Parapat: Sumatera Utara, Indonesia, 2015.

66. Aguilar-Martinez, S.; Valtiera-Pacheco, E. Composed indicator of community forest governance in San Miguel Topilejo, Mexico City. Forests 2021, 12, 1582. [CrossRef]

67. Andriyana, W.; Hogl, K. Decentralization drivers beyond legal provisions: The case of collaborative forest management in Java Island. Forests 2019, 10, 685. [CrossRef]

68. Krause, T.; Nielsen, M.R. Not seeing the forest for the trees: The oversight of defaunation in REDD+ and global forest governance. Forests 2019, 10, 344. [CrossRef]

69. Mulyani, M.; Jepson, P. Does the "one map initiative" represent a new path for forest mapping in Indonesia? Assessing the contribution of the REDD+ initiative in effecting forest governance reform. Forests 2017, 8, 14. [CrossRef]

70. Ordóñez, C.; Kendal, D.; Threlfall, C.G.; Hochuli, D.F.; Davern, M.; Fuller, R.A.; van der Ree, R.; Livesley, S.J. How urban forest managers evaluate management and governance challenges in their decision-making. Forests 2020, 11, 963. [CrossRef]

71. Subarudi Tata kelola kehutanan yang baik: Sebuah pembelajaran dari Kabupaten Sragen. J. Anal. Kebijak. Kehutan. 2008, 5, 179-192.

72. Agrawal, A.; Chhatre, A.; Hardin, R. Changing governance of the world's forests. Science 2008, 320, 1460-1462. [CrossRef] [PubMed]

73. Hidayat, H.; Siburian, R.; Yuliana, C.I. Gaharu alam, jaringan perdagangan, dan gaharu budidaya: Studi kasus Kalimantan Timur. J. Biol. Indones. 2020, 16, 99-110. [CrossRef]

74. Badan Pusat Statistik. Provinsi Maluku dalam Angka 2015; BPS: Ambon, Indonesia, 2015.

75. Indonesian National Standard. Gaharu SNI 7631: 2011; Indonesian National Standard: Jarkarta, Indonesia, 2011.

76. Darmokusumo, S.; Nugroho, A.A.; Botu, E.U.; Jehamat, A.; Benggu, M. Upaya memperluas kawasan ekonomis cendana di Nusa Tenggara Timur. Ber. Biol. 2001, 5, 509-514. 
77. Raya, B.; Afifuddin, Y.; Batubara, R. Analisis pemasaran kemenyan (Styrax spp.): Studi Kasus : Kec. Pollung, Kab. Humbang Hasundutan. Peronema For. Sci. J. 2012, 1, 6.

78. Rimbawanto, A.; Kartikawati, N.K. Minyak Kayu Putih Dari Tanaman asli Indonesia Untuk Masyarakat Indonesia; Hardiyanto, E.B., Nirsatmanto, A., Eds.; Penerbit Kaliwangi: Yogyakarta, Indonesia, 2017; ISBN 978-979-3666-20-4.

79. Kartikawati, N.K.; Rimbawanto, A.; Susanto, M.; Baskorowati, L. Budidaya dan Prospek Pengembangan Kayuputih (Melaleuca Cajuput); Na'iem, M., Mahfudz, S.B., Eds.; IPB Press: Yogyakarta, Indonesia, 2014.

80. Central Agency on Statistics. Produksi Perusahaan Pembudidaya Tanaman Kehutanan Menurut Jenis Produksi $2014-2016$. Available online: https://www.bps.go.id/indicator/60/1851/2/produksi-perusahaan-pembudidaya-tanaman-kehutananmenurut-jenis-produksi.html (accessed on 21 September 2021).

81. Perum Perhutani. 4.0+: Connecting through Connectivity; Perum Perhutani: Jakarta, Indonesia, 2019.

82. Pratama, A.A.; Laraswati, D.; Soraya, E.; Arfenda, F.C.; Kurniawan, H.; Rahayu, S.; Widyaningsih, T.S.; Harsono, P. Semburat Cahaya Istimewa: Inovasi dan Kreasi Pengelolaan Hutan KPH Yogyakarta; Nurjaman, A.S.B., Adiwinata, A., Maryudi, A., Eds.; Fakultas Kehutanan Universitas Gadjah Mada: Yogyakarta, Indonesia, 2021; ISBN 978-979-3178-25-7.

83. Lukito, M. Estimasi produksi basah daun minyak kayu putih (Studi Kasus BKPH Sukun KPH Madiun). Scribd 2011, 12, 36-48.

84. Maulidah, S. Struktur pasar minyak kayu putih (Melaleuca leucadendron oil) (Studi kasus di Kecamatan Namlea Kabupaten Buru-Maluku). J. Manaj. Pemasar. 2010, 5, 9-13. [CrossRef]

85. Liu, Y.; Chen, H.; Yang, Y.; Zhang, Z.; Wei, J.; Men, H.; Chen, W.; Feng, J.; Gan, B.; Chen, X.; et al. Whole-tree agarwood-inducing technique: An efficient novel technique for producing high-quality agarwood in cultivated Aquilaria sinensis trees. Molecules 2013, 18, 3086-3106. [CrossRef] [PubMed]

86. Susmianto, A.; Turjaman, M.; Setio, P. Rekam Jejak Gaharu Inokulasi; Forda Press: Jawa Barat, Indonesia, 2014; ISBN 9786021427439.

87. Aswandi; Kholibrina, C.R. Growth and yield model for non-timber forest product of kemenyan (Styrax sumatrana) J.J. Sm in Tapanuli, North Sumatra. In Proceedings of the IOP Conference Series: Earth and Environmental Science, Medan, Indonesia, 7-8 November 2018; Volume 122

88. Aswandi, A.; Kholibrina, C.R. The grading classification for Styrax sumatrana resins based on physico chemical characteristics using two-step cluster analysis. IOP Conf. Ser. Mater. Sci. Eng. 2020, 935, 012013. [CrossRef]

89. Kholibrina, C.R.; Aswandi, A. Increasing added-value of styrax resin through post-harvesting techniques improvement and essential oil based product innovation. IOP Conf. Ser. Earth Environ. Sci. 2021, 713, 012045. [CrossRef]

90. Idris, M.M.; Soenarno, S. Penerapan metode Tree length logging skala operasional di areal teknik silvikultur intensif (Studi kasus di PT. Sarmento Parakanca Timber). Penelit. Has. Has. Hutan 2015, 33, 19-34. [CrossRef]

91. Khandge, R.; Sane, S.; Khatri, N.; Satao, N. Extraction of essential oils: Eucalyptus oil. J. Emerg. Technol. Innov. Res. 2017, 4. [CrossRef]

92. Jok, V.A.; Radzi, N.C.; Hamid, K.H.K. Agarwood oil yield as a result of changes in cell morphology due to soaking process. Procedia - Soc. Behav. Sci. 2015, 195, 2443-2450. [CrossRef]

93. Kurniawati, F.; Ariyani, M. Pengaruh media tanam dan pemupukan NPK terhadap pertumbuhan bibit Damar mata kucing (Shorea javanica). Sains Tanah J. Soil Sci. Agroclimatol. 2013, 10, 9-18. [CrossRef]

94. Tan, C.S.; Isa, N.M.; Ismail, I.; Zainal, Z. Agarwood induction: Current development and future perspectives. Front. Plant Sci. 2019, 10, 1-13. [CrossRef]

95. López-Sampson, A.; Page, T. History of use and trade of agarwood. Econ. Bot. 2018, 72, 107-129. [CrossRef]

96. Binnqüist, C.L.; Shanley, P. Riches of the Forest: Food, Spices, Crafts, and Resins of Asia; Cifor: Bogor, Indonesia, 2004; Volume 2, ISBN 9793361182.

97. Adhikari, S.R.; Pokhrel, K.; Baral, S.D. Economic value of agarwood and its prospects of cultivation. Int. J. Appl. Sci. Biotechnol. 2021, 9, 23-31. [CrossRef]

98. Barden, A.; Anak, N.A.; Mulliken, T.; Song, M. Heart of the Matter: Agarwood Use and Trade and CITES Implementation for Aquilaria Malaccensis. TRAFFIC International: Cambridge, UK, 2000; pp. 1-52.

99. Burkill, I.H. A dictionary of the economic products of the Malay Peninsula. A Dict. Econ. Prod. Malay Penins. 1936, 2, 139-141. [CrossRef]

100. Chakrabarty, K.; Kuner, A. Trade in Agarwood; TRAFFIC-India: New Delhi, India, 1994.

101. Liu, Y.; Wei, J.; Gao, Z.; Zhang, Z.; Lyu, J. A review of quality assessment and grading for agarwood. Chin. Herb. Med. 2017, 9, 22-30. [CrossRef]

102. Yaacob, S. Agarwood: Trade and CITES Implementation in Malaysia. Unpublished Report Prepared for TRAFFIC Southeast Asia. Malaysia, 1999.

103. Van Beek, H.H.; Phillips, D. Agarwood: Trade and CITES Implementation in Southeast Asia. Unpublished Report Prepared for TRAFFIC Southeast Asia. Malaysia, 1999.

104. Murthy, M.C.; Veena, K. A bird view of customer perceptions towards the soaps and detergents of Bangalore. Int. J. Curr. Res. 2015, 7, 18060-18064.

105. Arpi, N. Pembuatan minyak kemenyan (minyak obat tradisional khas Aceh) dengan variasi jenis bahan baku minyak dan konsentrasi bahan pewangi. J. Teknol. dan Ind. Pertan. Indones. 2013, 5. [CrossRef]

106. Aswandi, A.; Kholibrina, C.R. Phenotypic and environmental determinants factors of incense Toba (Styrax sumatrana) resin productivity. J. Penelit. Kehutan. Sumatrana 2017, 1, 1-9. 
107. Page, T.; Tate, H.; Bunt, C.; Potrawiak, A.; Berry, A. Opportunities for the Smallholder Sandalwood Industry in Vanuatu; ACIAR Technical Reports: Canberra, Indonesia, 2012.

108. Peeris, M.K.P.; Senarath, W.T.P.S.K. In vitro propagation of Santalum album L. J. Natl. Sci. Found. Sri Lanka 2015, 43, 265-272. [CrossRef]

109. Faizal, A.; Azar, A.W.P.; Turjaman, M.; Esyanti, R.R. Fusarium solani induces the formation of agarwood in Gyrinops versteegii (Gilg.) Domke branches. Symbiosis 2020, 81, 15-23. [CrossRef]

110. Faizal, A.; Esyanti, R.R.; Aulinisa, E.N.; Irawati; Santoso, E.; Turjaman, M. Formation of agarwood from Aquilaria malaccensis in response to inoculation of local strains of Fusarium solani. Trees 2017, 31, 189-197. [CrossRef]

111. Putri, N.; Karlinasari, L.; Turjaman, M.; Wahyudi, I.; Nandika, D. Evaluation of incense-resinous wood formation in agarwood (Aquilaria malaccensis Lam.) using sonic tomography. Agric. Nat. Resour. 2017, 51, 84-90. [CrossRef]

112. Central Agency on Statistics. In Provinsi Maluku Dalam Angka 2018; Ambon, Indonesia; 2019. Available online: https:// maluku.bps.go.id/publication/2018/08/16/ff1f52bdbd1b5938d5ef6206/provinsi-maluku-dalam-angka-2018.html (accessed on 9 August 2021).

113. Central Agency on Statistics. Provinsi Maluku Dalam Angka 2017. Ambon, Indonesia, 2018. Available online: https:// maluku.bps.go.id/publication/2017/08/11/e6c4e799e2968469a4557ae1/provinsi-maluku-dalam-angka-2017.html (accessed on 9 August 2021).

114. Te Velde, D.W.; Rushton, J.; Schreckenberg, K.; Marshall, E.; Edouard, F.; Newton, A.; Arancibia, E. Entrepreneurship in value chains of non-timber forest products. For. Policy Econ. 2006, 8, 725-741. [CrossRef]

115. Grivins, M. A comparative study of the legal and grey wild product supply chains. J. Rural Stud. 2016, 45, 66-75. [CrossRef]

116. Astana, S.; Djaenudin, D.; Parlinah, N.; Prawesti Suka, A. Analisis distribusi margin tataniaga minyak kayu putih. J. Penelit. Sos. dan Ekon. Kehutan. 2007, 4, 205-219. [CrossRef]

117. Semiadi, G.; Wiriadinata, H.; Waluyo, E.B.; Darnaedi, D. Rantai pasokan produk tumbuhan gaharu (Aquilaria spp.) asal Merauke, Papua. Bul. Plasma Nutfah 2010, 16, 150-159. [CrossRef]

118. Howes, M.-J.R.; Simmonds, M.S.J.; Kite, G.C. Evaluation of the quality of sandalwood essential oils by gas chromatography-mass spectrometry. J. Chromatogr. A 2004, 1028, 307-312. [CrossRef] [PubMed]

119. Lawrence, B.M. Progress in essential oils. Perfum. Flavorist 1997, 22, 71-83.

120. Ramanan S., S.; George, A.K.; Chavan, S.B.; Kumar, S.; Jayasubha, S. Progress and future research trends on Santalum album: A bibliometric and science mapping approach. Ind. Crop. Prod. 2020, 158, 10. [CrossRef]

121. Rachmat, H.H.; Susilowati, A.; Elfiati, D.; Hartini, K.S.; Faradillah, W.N. Strong genetic differentiation of the endemic rosinproducing tree Styrax sumatrana (Styracaceae) in North Sumatra, Indonesia. Biodiversitas 2017, 18, 1331-1335. [CrossRef]

122. Hai, H.N.T.; Rimbawanto, A.; Kartikawati, N.K.; Wu, H. Genetic improvement for essential oil yield and quality in Melaleuca cajuputi. Ind. Crop. Prod. 2019, 137, 681-686.

123. Nurochman, D.; Matangaran, J.R.; Santosa, G.; Suharjito, D.; Sari, R.K. Autecology and morphological properties of sandalwood (Santalum album) in Pidie District, Aceh, Indonesia. Biodiversitas 2018, 19, 406-412. [CrossRef]

124. Achmad, H.N.; Rana, H.E.; Fadilla, I.; Fajar, A.; Manurung, R.; Abduh, M.Y. Determination of yield and chemical composition of eucalyptus oil from different species and locations in Indonesia. Biol. Nat. Resour. Eng. J. 2018, 1, 36-49.

125. Pasaribu, G.T.; Waluyo, T.K.; Pari, G. Analysis of chemical compounds distinguisher for agarwood qualities. Indones. J. For. Res. 2015, 2, 1-7. [CrossRef]

126. Nurlaila, I.; Mohd, A.N.A.; Mailina, J.; Mohd, H.F.R.; Saiful, N.T.; Mohd, N.T. Analysis of high quality agarwood oil chemical compounds by means of SPME/GC-MS and Z-score technique. Malays. J. Anal. Sci. 2013, 17, 403-413.

127. Santha, S.; Dwivedi, C. Anticancer effects of sandalwood (Santalum album). Anticancer Res. 2015, 35, 3137-3145.

128. Ortiz, C.; Morales, L.; Sastre, M.; Haskins, W.E.; Matta, J. Cytotoxicity and genotoxicity assessment of sandalwood essential oil in human breast cell lines MCF-7 and MCF-10A. Evid.-Based Complement. Altern. Med. 2016, 2016, 3696232. [CrossRef]

129. Castel, C.; Fernandez, X.; Lizzani-Cuvelier, L.; Perichet, C.; Lavoine, S. Characterization of the chemical composition of a byproduct from Siam benzoin gum. J. Agric. Food Chem. 2006, 54, 8848-8854. [CrossRef] [PubMed]

130. Atia Sharif, H.N.; Rehman, R.; Mushtaq, A.; Rashid, U.A. Review on bioactive potential of Benzoin resin. Int. J. Chem. Biochem. Sci. 2016, 10, 106-110.

131. Pastorova, I.; De Koster, C.G.; Boon, J.J. Analytical study of free and Ester bound benzoic and cinnamic acids of gum benzoin resins by GC-MS and HPLC-frit FAB-MS. Phytochem. Anal. Int. J. Plant Chem. Biochem. Tech. 1997, 8, 63-73. [CrossRef]

132. Hovaneissian, M.; Archier, P.; Mathe, C.; Culioli, G.; Vieillescazes, C. Analytical investigation of styrax and benzoin balsams by HPLC-PAD-fluorimetry and GC-MS. Phytochem. Anal. 2008, 19, 301-310. [CrossRef]

133. Abd El-Razek, M.H. Triterpenes from Styrax benzoin. Pharma Chem. 2018, 10, 30-34.

134. Filippi, J.-J.; Castel, C.; Fernandez, X.; Rouillard, M.; Gaysinski, M.; Lavoine-Hanneguelle, S. An unusual acenaphthylene-type sesquiterpene hydrocarbon from Siam and Sumatra benzoin gum. Phytochem. Lett. 2009, 2, 216-219. [CrossRef]

135. Pujiarti, R.; Ohtani, Y.; Ichiura, H. Physicochemical properties and chemical compositions of Melaleuca leucadendron leaf oils taken from the plantations in Java, Indonesia. J. Wood Sci. 2011, 57, 446-451. [CrossRef]

136. Sutrisno, S.; Retnosari, R.; Asmaningrum, H.P. Profile of the Indonesian essential oil from melaleuca cajuputi. In Proceedings of the Seminar Nasional Kimia-National Seminar on Chemistry (SNK 2018), Surabaya, Indonesia, 22 September 2018 ; pp. 14-19. 
137. Kucharska, M.; Frydrych, B.; Wesolowski, W.; Szymanska, J.A.; Kilanowicz, A. A comparison of the composition of selected commercial sandalwood oils with the International Standard. Molecules 2021, 26, 2249. [CrossRef]

138. Godlewska-żyłkiewicz, B.; Świsłocka, R.; Kalinowska, M.; Golonko, A.; Świderski, G.; Arciszewska, Ż.; Nalewajko-Sieliwoniuk, E.; Naumowicz, M.; Lewandowski, W. Biologically active compounds of plants: Structure-related antioxidant, microbiological and cytotoxic activity of selected carboxylic acids. Materials 2020, 13, 4454. [CrossRef]

139. Sudradjat, S.E. Minyak kayu putih, obat alami dengan banyak khasiat: Tinjauan sistematik. J. Kedokt. Meditek 2020, 26, 51-59. [CrossRef]

140. Ulfa, R.F.; Haryuni, S.; Ediatmi, E. The effect aromatherapy cajuput oil concerning emesis gravidarum on pregnant women trimester 1 in independent midwife's clinic Ny F Ponorogo. J. Delima Harapan 2018, 5, 17-23. [CrossRef]

141. Chinese Pharmacopoeia. National Pharmacopoeia Committee Pharmacopoeia of the People's Republic of China; Chinese Medical Science and Technology Press: Beijing, China, 2015; pp. 185-186.

142. Wang, S.; Yu, Z.; Wang, C.; Wu, C.; Guo, P.; Wei, J. Chemical constituents and pharmacological activity of agarwood and Aquilaria plants. Molecules 2018, 23, 342. [CrossRef]

143. Bhuiyan, N.I.; Begum, J.; Bhuiyan, N. Analysis of essential oil eagle wood tree (Aquilaria agallocha Roxb.) by gas chromatography mass spectrometry. Bangladesh J. Pharmacol. 2009, 4, 24-28.

144. Idm'Hand, E.; Msanda, F.; Cherifi, K. Ethnobotanical study and biodiversity of medicinal plants used in the Tarfaya Province, Morocco. Shengtai Xuebao Acta Ecol. Sin. 2020, 40, 134-144. [CrossRef]

145. Andesmora, E.; Muhadiono, M.; Hilwan, I. Ethnobotanical study of plants used by people in Hiang Indigenous Forest Kerinci, Jambi. J. Trop. Life Sci. 2017, 7, 95-101. [CrossRef]

146. Kim, J.H.; Liu, K.H.; Yoon, Y. Essential leaf oils from Melaleuca cajeputi. In Proceedings of the WOCMAP III. Traditional Medicine and Nutraceutical, Chiang Mai, Thailand, 31 March 2005; pp. 65-72.

147. Mehvish, S.; Barkat, M.Q. Phytochemical and antioxidant screening of Amomum subulatum, Elettaria cardamomum, Emblica officinalis, Rosa damascene, Santalum album and Valeriana officinalis and their effect on stomach, liver and heart. Matrix Sci. Med. 2018, 2, 28-33. [CrossRef]

148. Bakar, F.I.A.; Bakar, M.F.A.; Abdullah, N.; Endrini, S.; Rahmat, A. A review of Malaysian medicinal plants with potential anti-inflammatory activity. Adv. Pharmacol. Sci. 2018, 2018, 8603602. [CrossRef]

149. Sindhu, R.K.; Upma, K.A.; Arora, S. Santalum album linn: A review on morphology, phytochemistry and pharmacological aspects. Int. J. PharmTech Res. 2010, 2, 914-919.

150. Mohankumar, A.; Kalaiselvi, D.; Levenson, C.; Shanmugam, G.; Thiruppathi, G.; Nivitha, S.; Sundararaj, P. Antioxidant and stress modulatory efficacy of essential oil extracted from plantation-grown Santalum album L. Ind. Crop. Prod. 2019, $140,111623$.

151. Younis, N.S. Doxorubicin-induced cardiac abnormalities in rats: Attenuation via sandalwood oil. Pharmacology 2020, 105, 520-528. [CrossRef] [PubMed]

152. Misra, B.B.; Dey, S. Comparative phytochemical analysis and antibacterial efficacy of in vitro and in vivo extracts from E ast I ndian sandalwood tree (Santalum album L.). Lett. Appl. Microbiol. 2012, 55, 476-486. [CrossRef] [PubMed]

153. Shamsi, T.N.; Parveen, R.; Afreen, S.; Azam, M.; Fatma, T.; Haque, Q.M.R.; Fatima, S. In-vitro antibacterial and antioxidant activities of Sandalwood (Santalum album). Austin J. Biotechnol. Bioeng. 2014, 1, 2-2014.

154. Moy, R.L.; Levenson, C. Sandalwood album oil as a botanical therapeutic in dermatology. J. Clin. Aesthet. Dermatol. $2017,10,34$.

155. Setzer, W.N. Essential oils and anxiolytic aromatherapy. Nat. Prod. Commun. 2009, 4, 1934578X0900400928. [CrossRef]

156. Kyle, G. Evaluating the effectiveness of aromatherapy in reducing levels of anxiety in palliative care patients: Results of a pilot study. Complement. Ther. Clin. Pract. 2006, 12, 148-155. [CrossRef] [PubMed]

157. Paulpandi, M.; Kannan, S.; Thangam, R.; Kaveri, K.; Gunasekaran, P.; Rejeeth, C. In vitro anti-viral effect of $\beta$-santalol against influenza viral replication. Phytomedicine 2012, 19, 231-235. [CrossRef] [PubMed]

158. Li, G.; Singh, A.; Liu, Y.; Sunderland, B.; Li, D. Comparative effects of sandalwood seed oil on fatty acid profiles and inflammatory factors in rats. Lipids 2013, 48, 105-113. [CrossRef] [PubMed]

159. Burdock, G.A.; Carabin, I.G. Safety assessment of sandalwood oil (Santalum album L.). Food Chem. Toxicol. 2008, 46, 421-432. [CrossRef]

160. Saraswati, S.; Kumar, S.; Alhaider, A.A. $\alpha$-santalol inhibits the angiogenesis and growth of human prostate tumor growth by targeting vascular endothelial growth factor receptor 2-mediated AKT/mTOR/P70S6K signaling pathway. Mol. Cancer 2013, 12, 147. [CrossRef] [PubMed]

161. Dozmorov, M.G.; Yang, Q.; Wu, W.; Wren, J.; Suhail, M.M.; Woolley, C.L.; Young, D.G.; Fung, K.-M.; Lin, H.-K. Differential effects of selective frankincense ( $\mathrm{Ru}$ Xiang) essential oil versus non-selective sandalwood (Tan Xiang) essential oil on cultured bladder cancer cells: A microarray and bioinformatics study. Chin. Med. 2014, 9, 18. [CrossRef]

162. Dwivedi, C.; Valluri, H.B.; Guan, X.; Agarwal, R. Chemopreventive effects of $\alpha$-santalol on ultraviolet B radiation-induced skin tumor development in SKH-1 hairless mice. Carcinogenesis 2006, 27, 1917-1922. [CrossRef]

163. Chilampalli, C.; Zhang, X.; Kaushik, R.S.; Young, A.; Fahmy, H.; Zeman, D.; Dwivedi, C.; Hildreth, M.B. Chemopreventive effects of combination of honokiol and magnolol with $\alpha$-santalol on skin cancer developments. Drug Discov. Ther. 2011, 7, 109-115. [CrossRef]

164. Dattner, A.M. From medical herbalism to phytotherapy in dermatology: Back to the future. Dermatol. Ther. 2003, 16, 106-113. [CrossRef] 
165. Sica, D.A. Diuretic use in renal disease. Nat. Rev. Nephrol. 2012, 8, 100-109. [CrossRef]

166. Septiana, S.; Bachtiar, B.M.; Yuliana, N.D.; Wijaya, C.H. Cajuputs candy impairs Candida albicans and Streptococcus mutans mixed biofilm formation in vitro. F1000Research 2019, 8, 1923. [CrossRef]

167. Muchtaridi, M.; Tjiraresmi, A.; Febriyanti, R. Analysis of active compounds in blood plasma of mice after inhalation of Cajuput essential oil (Melaleuca leucadendron L.). Indones. J. Pharm. 2016, 26, 219. [CrossRef]

168. Marfuah, D. Experience of adolecent with Premenstrual Syndrome. In Proceedings of the International Conference on Disaster Management \& Infection Control, Seville, Spain, 18-19 July 2017; Volume 1, p. 31.

169. Assunção, A.F.C.; Rodrigues, N.D.S.; da Costa Sampaio, A.V.; dos Santos Silva, K.; da Silva, L.R.; dos Santos Martins, M.G.; de Castro Almeida, F.R.; da Silva Lopes, L.; Monte, S.M.; Marques, R.B. Alpha-terpineol: Evaluation and pharmacological screening as an antidepressant agent. Res. Soc. Dev. 2021, 10, e191101119571. [CrossRef]

170. Kim, T.H.; Ito, H.; Hayashi, K.; Hasegawa, T.; Machiguchi, T.; Yoshida, T. Aromatic constituents from the heartwood of Santalum album L. Chem. Pharm. Bull. 2005, 53, 641-644. [CrossRef] [PubMed]

171. Hamoud, R.; Sporer, F.; Reichling, J.; Wink, M. Antimicrobial activity of a traditionally used complex essential oil distillate (Olbas ${ }^{\circledR}$ Tropfen) in comparison to its individual essential oil ingredients. Phytomedicine 2012, 19, 969-976. [CrossRef]

172. Ukit, U.; Widiana, A.; Rahmawati, E.; Hasby, R.M. Antibacterial activities test of Cajuput leaf waste extract (Melaleuca cajuputi Powell) on pathogenic bacteria. J. Phys. Conf. Ser. 2019, 1402, 33030. [CrossRef]

173. Timur, W.W.; Latifah, F. Formulasi sediaan deodoran dalam bentuk krim menggunakan kombinasi aluminium sulfat dan minyak kayu cendana. Ad-Dawaa J. Pharm. Sci. 2019, 2, 6-15. [CrossRef]

174. Wijaya, C.H.; Sari, B.R.E.; Bachtiar, B.M. The potency of cajuputs candy in maintaining the competitive capacity of Streptococcus sanguinis upon Streptococcus mutans. J. Funct. Food Nutraceutical 2020, 1, 87-99. [CrossRef]

175. Mohamed, R.; Lee, S.Y.; Turjaman, M. Phylogenetic relatedness of several agarwood-production taxa (Thymelaeaceae) from Indonesia. Trop. Life Sci. Res. 2014, 29, 13-28.

176. Kashio, M.; Johnson, D.V. Monograph on Benzoin (Balsamic Resin from Styrax Species); Regional Office for Asia and the Pacific: Bangkok, Thailand, 2001.

177. Brophy, J.C.; Doran, J. Essential Oils of Tropical Asteromyrtus, Callistemon and Melaleuca Species: In Search of Interesting Oils with Commercial Potential; ACIAR Monograph: Canberra, Indonesia, 1996.

178. Faizal, A.; Esyanti, R.R.; Adn'ain, N.; Rahmani, S.; Azar, A.W.P.; Iriawati; Turjaman, M. Methyl jasmonate and crude extracts of Fusarium solani elicit agarwood compounds in shoot culture of Aquilaria malaccensis Lamk. Heliyon 2021, 7, e06725. [CrossRef]

179. Aqmarina Nasution, A.; Siregar, U.J.; Miftahudin; Turjaman, M. Identification of chemical compounds in agarwood-producing species Aquilaria malaccensis and Gyrinops versteegii. J. For. Res. 2020, 31, 1371-1380. [CrossRef]

180. Matsuo, Y.; Mimaki, Y. $\alpha$-Santalol derivatives from Santalum album and their cytotoxic activities. Phytochemistry 2012, 77, 304-311. [CrossRef]

181. Bommareddy, A.; Knapp, A.W.K.; Nemeth, A.; Steigerwalt, J.; Landis, T.; Vanwert, A.L.; Gorijavolu, H.P.; Dwivedi, C. Alphasantalol, a component of sandalwood oil inhibits migration of breast cancer cells by targeting the $\beta$-catenin pathway. Anticancer Res. 2018, 38, 4475-4480. [CrossRef] [PubMed]

182. Fox, J.E. Sandalwood: The royal tree. Biologist 2000, 47, 31-34.

183. Njurumana, G.N.; Marsono, D.; Irham; Sadono, R. Konservasi cendana berbasis masyarakat pada sistem Kaliwu di Pulau Sumba. J. Ilmu Lingkung. 2013, 11, 51-61. [CrossRef]

184. Sirait, E. Pengelolaan Sumberdaya Berbasis Kemasyarakatan dan Kearifan Lokal: Kasus Pengelolaan Cendana di Kabupaten Timor Tengah Selatan Provinsi Nusa Tenggara Timur. IPB: Bogor, Indonesia, 2005. Available online: http:// repository.ipb.ac.id/handle/12345678 9/41314 (accessed on 15 June 2021).

185. Matangaran, J.R.; Partiani, T.; Purnamasari, D.R. Faktor eksploitasi dan kuantifikasi limbah kayu dalam rangka peningkatan efisiensi pemanenan hutan alam. Bumi Lestari 2013, 13, 384-393.

186. Sandeep, C.; Manohara, T.N. Sandalwood in India: Historical and cultural significance of Santalum album L. as a basis for its conservation. NeBIO 2019, 10, 235-242.

187. Rimbawanto, A.; Kartikawati, N.K.; Latumahina, F. Conservation and utilization of Melaleuca cajuputi sub sp cajuputi, an indigenous species in Moluccas Island, Indonesia. IOP Conf. Ser. Earth Environ. Sci. Int. Conf. Sustain. Util. Nat. Resour. 2021, 800, 012040. [CrossRef]

188. Kholibrina, C.R.; Susilowati, A. Flowering and fruiting phenology of Kemenyan toba (Styrax sumatrana J.J.Sm.) in AekNauli forest, North Sumatra. In Proceedings of the IOP Conference Series: Earth and Environmental Science, Medan, Indonesia, 7-8 November 2018; Volume 122.

189. Rahman, N.S. Robust in vitro propagation of sandalwood through direct organogenesis. In Proceedings of the Proceedings International Conference on Biotechnology, West Java, Indonesia, 13-14 November 2012; pp. 89-96.

190. Indrioko, S.; Ratnaningrum, Y.W.N. Habitat loss caused clonality, genetic diversity reduction and reproductive failure in Santalum album (Santalaceae), an endangered endemic species of Indonesia. Procedia Environ. Sci. 2015, 28, 657-664. [CrossRef]

191. Cahyaningsih, R.; Phillips, J.; Magos Brehm, J.; Gaisberger, H.; Maxted, N. Climate change impact on medicinal plants in Indonesia. Glob. Ecol. Conserv. 2021, 30, e01752. [CrossRef]

192. Sitepu, I.R.; Santoso, E.; Siran, S.A.; Turjaman, M. Fragrant Wood Gaharu: When the Wild Can No Longer Provide; Indonesia's Work Programme: Jakarta, Indonesia, 2011; Volume 50, ISBN 9789793145884. 
193. Seran, Y.N.; Sudarto, S.; Hakim, L.; Arisoesillaningsih, E.; Arisoesilaningsih, E. Sandalwood (Santalum album) growth and farming success strengthen its natural conservation in the Timor Island, Indonesia. Biodiversitas 2018, 19, 1586-1592. [CrossRef]

194. Ingram, V.J. Win-Wins in Forest Product Value Chains? How Governance Impacts the Sustainability of Livelihoods Based on Non-Timber Forest Products from Cameroon; African Studies Collection: Cape Town, South Africa, 2014; ISBN 9789054481379.

195. Shackleton, C.M.; Ticktin, T.; Pandey, A.K. Ecological Sustainability for Non-Timber Forest Products; Routledge: Oxfordshire, UK, 2015; ISBN 9781317916123.

196. Njurumana, G.N. Pelestarian cendana (Santalum album) berbasis masyarakat di Kabupaten Sumba Tengah, Nusa Tenggara Timur. In Proceedings of the Prosiding Seminar Nasional Masyarakat Biodiversity Indonesia, Medan, Indonesia, 13 June 2015; Volume 1, pp. 1605-1609.

197. Jung, D. The cultural biography of Agarwood-perfumery in Eastern Asia and the Asian neighbourhood. J. R. Asiat. Soc. 2013, 23, 103-125. [CrossRef]

198. Arnold, J.E.; Perez, M.R. The role of non-timber forest products in conservation and development. In Income from the Forest: Methods for the Development and Conservation of Forest Products for Local Communities; Wollenberg, E., Ingles, A., Eds.; Center for International Forestry Research: Bogor, Indonesia, 1998; pp. 17-41, ISBN 9798764196.

199. Wollenberg, E. Methods for assessing the conservation and development of forest products: What we know and what we have yet to learn. In Incomes from the Forest: Methods for the Development and Conservation of Forest Products for Local Communities; Wollenberg, E., Ingles, A., Eds.; Center for International Forestry Research: Bogor, Indonesia, 1998; pp. 1-16.

200. Stockdale, M. Steps to Sustainable and Community-Based NTFP Management: A Manual Written with Special Reference to South and Southeast Asia, 2005th ed.; NTFP Exchange Programme for South and Southeast Asia: Quezon City, Philippines, 2005; ISBN 9799935504.

201. Destri, D.; Mutaqien, Z.; Rozak, A.H. Agarwood in the forest community and its potential depletion in West Papua. J. Penelit. Kehutan. Wallacea 2020, 9, 1-12. [CrossRef]

202. Al Hasan, R.; Wahyuni, R.; Dharma, J.; No, B.; Langko, D.; Barat, L.L.; Tenggara, N. Potret pembudidayaan gaharu di Lombok Utara. Prosiding 2019, 6, 517-525.

203. Indonesia, P.R. Menteri Kehakiman Peraturan Pemerintah Republik Indonesia Nomor 6 Tahun 1956 Tentang Pernyataan Berlakunya Peraturan Ordonnantie Aetherische Olien; Pemerintah Republik Indonesia: Jakarta, Indonesia, 1956.

204. Smith, H.; Idrus, S. Estimasi produksi minyak kayu putih pada industri kecil penyulingan di Maluku. Maj. BIAM 2016, 12, 8-13.

205. Miharto, D.S.; Karimuna, S.R.; Fachlevy, A.F. Gambaran kualitas air sumur gali pada pemukiman warga di sekitar bekas tempat pembuangan akhir (TPA) Sampah Punggolaka Kota Kendari 2016. J. Ilm. Mhs. Kesehat. Masy. 2017, 2, 1-9.

206. BanoEt, H.H. Peranan cendana dalam perkonomian NTT: Dulu dan kini. Ber. Biol. 2001, 5, 469-475.

207. Jensen, A. Valuation of non-timber forest products value chains. For. Policy Econ. 2009, 11, 34-41. [CrossRef]

208. Bhowmik, D.; Biswas, D.; Sampath Kumar, K.P. Recent aspect of ethnobotanical application and medicinal properties of traditional Indian herbs Santalum album. Int. J. Chem. Sci. Res. 2011, 1, 21-27.

209. Karlinasari, L.; Indahsuary, N.; Kusumo, H.T.; Santoso, E.; Turjaman, M.; Nandika, D. Sonic and ultrasonic waves in agarwood trees (Aquilaria microcarpa) inoculated with Fusarium solani. J. Trop. For. Sci. 2015, 27, 351-356.

210. Siburian, R.H.S.; Siregar, U.J.; Siregar, I.Z.; Santoso, E.; Wahyudi, I. Anatomical characters of Aquilaria microcarpa interacting with Fusarium sp. Biotropia 2013, 20. [CrossRef]

211. Peng, C.S.; Osman, M.F.; Bahari, N.; Nuri, E.A.K.; Zakaria, R.; Rahim, K.A. Production of Agarwood resin in Aquilaria beccariana using inducement technology. J. Agrobiotechnol. 2021, 12, 57-67. [CrossRef]

212. Novriyanti, E.; Santosa, E.; Syafii, W.; Turjaman, M.; Sitepu, I.R. Anti fungal activity of wood extract of Aquilaria crassna Pierre ex Lecomte against agarwood-inducing fungi, Fusarium solani. Indones. J. For. Res. 2010, 7, 155-165. [CrossRef]

213. Rahayu, G. Fragrance formation in Aquilaria spp. shoot culture induced by Acremonium sp. Microbiol. Indones. 2010, 4, 55-59. [CrossRef]

214. Auri, A.; Faridah, E.; Sumardi, S.; Hardiwinoto, S. The effect of crown pruning and induction of Acremonium sp. on agarwood formation in Gyrinops caudata in West Papua, Indonesia. Biodivers. J. Biol. Divers. 2021, 22, 2604-2611. [CrossRef]

215. Mega, I.M.; Kartini, N.L. Identification of agarwood Sapwood chemical components from sungal inoculation results on Gyrinops versteegii (Gilg.) Domke plants. Int. J. Biosci. Biotechnol. 2020, 8, 80-89.

216. Subowo, Y.B. Jamur pembentuk gaharu sebagai penjaga kelangsungan hidup tanaman gaharu (Aquilaria sp). J. Teknol. Lingkung. 2016, 11, 167-173. [CrossRef]

217. Aswandi, A.; Kholibrina, C.R. Ethnopharmacological properties of essential oils from natural forests in Northern Sumatra. IOP Conf. Ser. Earth 2021, 715, 012077. [CrossRef]

218. Susilowati, A.; Kholibrina, C.R.; Rachmat, H.H.; Munthe, M.A. Phylogeny of kemenyan (Styrax sp.) from North Sumatra based on morphological characters. IOP Conf. Ser. Earth Environ. Sci. Int. Conf. Agric. Environ. Food Secur. 2018, 122, 012062. [CrossRef]

219. Susilowati, A.; Hendalastuti, H.; Kholibrina, C.R.; Ramadhani, R. Short Communication: Weak delineation of Styrax species growing in North Sumatra, Indonesia by matK + rbcL gene. Biodivers. J. Biol. Divers. 2017, 18, 1270-1274. [CrossRef]

220. Njurumana, G.N.; Ginoga, K.; Octavia, D. Sustaining farmers livelihoods through community forestry in Sikka, East Nusa Tenggara, Indonesia. Biodivers. J. Biol. Divers. 2020, 21. [CrossRef]

221. Burgess, T.I.; Howard, K.; Steel, E.; Barbour, E.L. To prune or not to prune; pruning induced decay in tropical sandalwood. For. Ecol. Manag. 2018, 430, 204-218. [CrossRef] 